\title{
Bacterial-Polymer-Based Electrolytes: Recent Progress and Applications.
}

Torres, Fernando G., De-la-Torre, Gabriel Enrique, Gonzales, Karen N. y Troncoso, Omar P.

Cita:

Torres, Fernando G., De-la-Torre, Gabriel Enrique, Gonzales, Karen N. y Troncoso, Omar P. (2020). Bacterial-Polymer-Based Electrolytes: Recent Progress and Applications. ACS Applied Energy Materials, 3 (12), 11500-11515.

Dirección estable: https://www.aacademica.org/gabriel.e.delatorre/18 ARK: https://n2t.net/ark:/13683/podQ/uYo

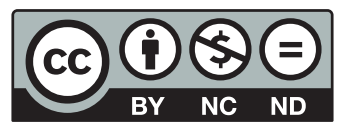




\title{
Bacterial-Polymer-Based Electrolytes: Recent Progress and Applications
}

\author{
Fernando G. Torres,* Gabriel E. De-la-Torre, Karen N. Gonzales, and Omar P. Troncoso
}

Cite This: https://dx.doi.org/10.1021/acsaem.0c02195

Read Online

ACCESS | Lill Metrics \& More | 回 Article Recommendations | st Supporting Information

ABSTRACT: Bacteria can naturally synthesize a wide range of biopolymers that have appealing material properties for numerous applications. In the past decade, the development of green electronics based on bacterial polymers has gained major attention. Polymer electrolytes are key components in electrochemical devices owing to their mechanical properties, thermal stability, and ionic conductivity. The present review focuses on the recent progress of bacterial-polymer-based electrolytes and their applications in electrochemical energy conversion and storage. First, we described the ion transfer mechanism of polymer electrolytes and the multiple approaches for improving ionic conductivity and mechanical properties. Then, we summarized the composition,
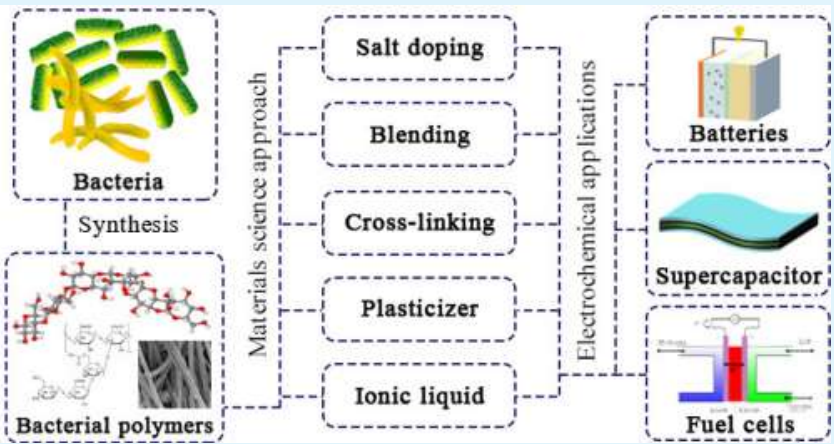
performance, and approaches applied for the development of multiple bacterial polymer electrolytes, namely, polysaccharides, polyanhydrides, and polyesters. Lastly, the practical applications of bacterial-polymer-based electrolytes in electrochemical energy storage and conversion, namely, fuel cells, batteries, supercapacitors, and other electrochemicals, are reviewed. Bacterial polymer electrolytes are presented as a fruitful, eco-friendly, and highperformance alternative for traditional solid polymer electrolytes.

KEYWORDS: bacterial polymers, biodegradable, polysaccharides, polyanhydrides, polyesters, electrolyte, xanthan, bacterial cellulose

\section{INTRODUCTION}

The increasing demand for advanced energy storage devices such as batteries and supercapacitors, with high energy density, long life cycle, flexibility, and environmentally friendliness, has brought an extensive search for alternative biobased materials to replace synthetic polymers used in different components of such electrochemical devices. In general, the main components in batteries and supercapacitors are the current collectors, the electrodes (cathode and anode), a separator membrane, and an electrolyte which is usually a salt solution providing the ion transport mechanism between the cathode and anode. ${ }^{1,2}$

Despite the fact that conventional liquid electrolytes used in electrochemical devices have high conductivity, their use is associated with high risk of leakage and corrosion, thereby leading to safety issues related with short-circuiting of electronic systems and the toxic effects of liquid electrolytes in contact with skin. ${ }^{2-4}$ Solid-state and quasi-solid-state (i.e., gel type) polymeric electrolytes have been developed to overcome the problems related to liquid electrolytes. ${ }^{5-8}$ The first solid-state polymer electrolyte, developed by Fenton, consisted of an alkali salt homogeneously dissolved in poly(ethylene oxide) (PEO). These PEO-based electrolytes featured ionic conductivities of the order of $10^{-8} \mathrm{~S} \mathrm{~cm}^{-1}$. Since then, several synthetic polymers hosts, such as poly(methyl methacrylate) (PMMA) and poly(vinylidene fluoride), have been employed to prepare solid electrolytes. ${ }^{5,10-14}$ These polymer-based electrolytes feature good conductivity, mechanical properties, and dimensional stability. However, they are made from synthetic non-biodegradable polymers that contribute to pollution and climate change. ${ }^{3,15}$

Some bacteria can naturally convert a variety of carbon sources into a wide range of biopolymers. These bacterial biopolymers are suitable for a wide range of industrial, medical, cosmetic, food, environmental, and energy applications. ${ }^{16-18}$ Polysaccharides, polyanhydrides, polyesters, and polyamides are among the most common biopolymers synthesized by bacteria. ${ }^{19}$ Some of these bacterial polymers are already commercially exploited. For instance, dextran (DEX) and xanthan polysaccharides have an annual production of around 2000 and 100,000 tons, respectively. ${ }^{19,20}$ One limitation of bacterial polymers for the development of novel electrochemical energy devices is their low intrinsic ionic conductivity. In the search for novel polymer electrolytes with

Received: September 7, 2020

Accepted: December 3, 2020 
enhanced performance, many researchers have carried out multiple approaches such as doping a polymer host with organic and inorganic salts and ionic liquids. ${ }^{21}$

Several reviews have addressed the biosynthesis, modifications, and industrial applications of bacterial polymers. Despite being a suitable candidate for polymer electrolytes, no previous reviews have focused on their use for the development of novel energy storage devices. In this paper, the recent advances of bacterial-polymer-based electrolytes for energy applications are reviewed. In the following sections, strategies for improving their performance in electrochemical device technology will be summarized. A comprehensive list of bacterial-polymer-based electrolytes, including different types of polysaccharides, polyanhydrides and polyesters, is presented. The main uses of bacterial-polymer-based electrolytes in electrochemical device applications including batteries, fuel cells, and supercapacitors are discussed. We aim to extend the available knowledge of bacterial polymers and describe their relevance and applied potential as electrolytes.

\section{APPROACHES FOR A BETTER PERFORMANCE}

2.1. Performance and Ion Transfer Mechanism. For many electrochemical devices, the properties of the polymer electrolytes in use are crucial for their performance and efficiency. The performance requirements for polymer electrolytes vary depending on the intended application. For instance, for lithium-ion batteries, the polymer electrolytes are required to have (1) high ionic conductivity, (2) appreciable lithium-ion transference number, (3) good mechanical strength, (4) large electrochemical stability window, and (5) excellent chemical and thermal stability. ${ }^{22}$ For direct methanol fuel cells (DMFCs), the effectiveness of polymer electrolytes depends on (1) the conductivity properties (ion exchange capacity, water uptake, and proton conductivity), (2) methanol permeability, (3) mechanical and thermal stability, and (4) morphology and elemental analysis. ${ }^{23}$ Lastly, for supercapacitors, key factors regarding polymer electrolytes are (1) ion mobility and conductivity, (2) thermal and chemical stability, and (3) operating voltage window. ${ }^{24}$ High ionic conductivity and optimal mechanical/thermal properties are generally desired for any application.

One of the determinant factors of ionic conductivity is the number of mobile ions in the polymer electrolyte. Polymer hosts alone exhibit very limited ionic conductivity. ${ }^{25}$ One of the most widely used approaches is adding salts to the polymer host as a source of mobile ions. Multiple salts have been reported to achieve good ionic conductivity in biopolymer electrolytes, such as lithium, ammonium, and magnesium salts. $^{26-28}$ The number of mobile ions varies depending on the level of salt dissociation in the polymer host. ${ }^{22}$ Typically, the degree of dissociation is associated with the lattice energy of the salt and physicochemical properties of the polymer host, such as the dielectric constant $(\varepsilon)$, the glass transition temperature $\left(T_{\mathrm{g}}\right)$, and the Hildebrand solubility parameter $(\delta) .^{29}$ For instance, Ulaganathan et al. compared the effect of different lithium salts $\left(\mathrm{LiBF}_{4}, \mathrm{LiClO}_{4}\right.$, and $\left.\mathrm{LiCF}_{3} \mathrm{SO}_{3}\right)$ on the performance of solid polymer electrolytes. ${ }^{30}$ The results indicated that electrolytes doped with $\mathrm{LiBF}_{4}$ exhibited the highest ionic conductivity. This was associated with $\mathrm{LiBF}_{4}$ having the lowest lattice energy $\left(699 \mathrm{~kJ} \mathrm{~mol}^{-1}\right)$, which allows an easier solvation of $\mathrm{Li}^{+}$ions in the polymer matrix. Also, the degree of crystallinity is an important factor. Mobile ions can move faster in the amorphous phase of polymer electrolytes than in the crystalline phase. ${ }^{31}$ Thus, polymer materials with a low degree of crystallinity are desirable. On the other hand, conductivity values increase with temperature. The dependence of ionic conductivity on temperature follows one of two mechanisms. ${ }^{32}$ The first is the Arrhenius behavior

$$
\sigma(T)=\sigma_{0} \exp \left(-E_{\mathrm{a}} / K T\right)
$$

where $\sigma$ is the conductivity, $K$ is the gas constant, $T$ is the temperature, $\sigma_{0}$ is a constant related to the conductivity at $0 \mathrm{~K}$, and $E_{\mathrm{a}}$ is the activation energy for ion transport. ${ }^{3,34}$ The second is the Vogel-Fulcher-Tammann behavior

$$
\sigma(T)=\sigma_{0} T^{-1 / 2} \exp \left(-B / T-T_{0}\right)
$$

where $B$ is the pseudoactivation energy and $T_{0}$ is the equilibrium glass transition temperature..$^{22,32,35}$ Ideally, polymer electrolytes are required to reach $\sim 10^{-3} \mathrm{~S} \mathrm{~cm}^{-1}$ of ionic conductivity for a wide range of applications. ${ }^{32,36,37}$

Hydrogel polymer electrolytes generally exhibit higher ionic conductivity than solid electrolytes owing to the ionic transport mechanism occurring in each state. Ionic migration in solid polymer electrolytes undergoes translational motion by hopping into a free space created by the constant redistribution of free spaces in the polymeric material, which significantly limits the ionic conductivity. ${ }^{38}$ Hydrogels consist of a $3 \mathrm{D}$ interconnected water-filled porous network created by a hydrogen-bonded cross-linking self-assembly mechanism. ${ }^{39}$ The porous network serves as a channel for free ions to flow easily. The flow of ions in the porous network varies depending on the type of ion and pore size. ${ }^{40}$ Importantly, the water content in the gel electrolyte may enhance the ionic conductivity but limit the mechanical strength. ${ }^{41}$

2.2. Complementary Approaches. 2.2.1. Blends. Polymer blending is the process of physically mixing multiple polymers without undergoing chemical bonding between polymer types. ${ }^{21}$ Depending on the selection of polymers for blending, the blended material can exhibit modified mechanical properties that can be tailored for specific applications. ${ }^{42}$ For instance, Aziz et al. used a methylcellulose:DEX (MC:DEX) polymer-blend-based electrolyte doped with $\mathrm{NH}_{4} \mathrm{I}$ salt for the development of an electrical double layer capacitor (EDLC) application. ${ }^{43}$ The MC:Dex composition with $40 \mathrm{wt} \% \mathrm{NH}_{4} \mathrm{I}$ showed an ionic conductivity of $1.12 \times 10^{-3} \mathrm{~S} \mathrm{~cm}^{-1}$. DEX has also been blended with chitosan to prepare a solid polymeric electrolyte with the incorporation of various amounts of lithium perchlorate $\left(\mathrm{LiClO}_{4}\right) .{ }^{44}$ The ionic conductivity of the blended $\mathrm{DEX} /$ chitosan membrane with 40 wt $\% \mathrm{LiClO}_{4}$ was $5.16 \times 10^{-3} \mathrm{~S} \mathrm{~cm}^{-1}$. Kadir et al. reported that blending DEX with chitosan significantly reduced the degree of crystallinity, which is beneficial for enhancing ionic conductivity. ${ }^{45}$

2.2.2. Cross-Linking. In cross-linked polymers, the polymer chains are linked to each other by covalent bonds. Crosslinking generally increases the stiffness or mechanical rigidity of the polymeric material. ${ }^{46}$ In some cases, it may increase the amorphous phase of the polymeric materials. ${ }^{47}$ Chemical crosslinking is carried out by adding a cross-linking agent. The mechanical properties of polymer electrolytes vary depending on the concentration of the cross-linking agent. ${ }^{48}$ Some crosslinking agents used in biopolymer-based electrolytes are formaldehyde, poly(ethylene glycol) diacrylate, and glutaraldehyde, among others. ${ }^{49-51}$ A polymeric network can also be obtained without the use of chemical cross-linkers. This is the 

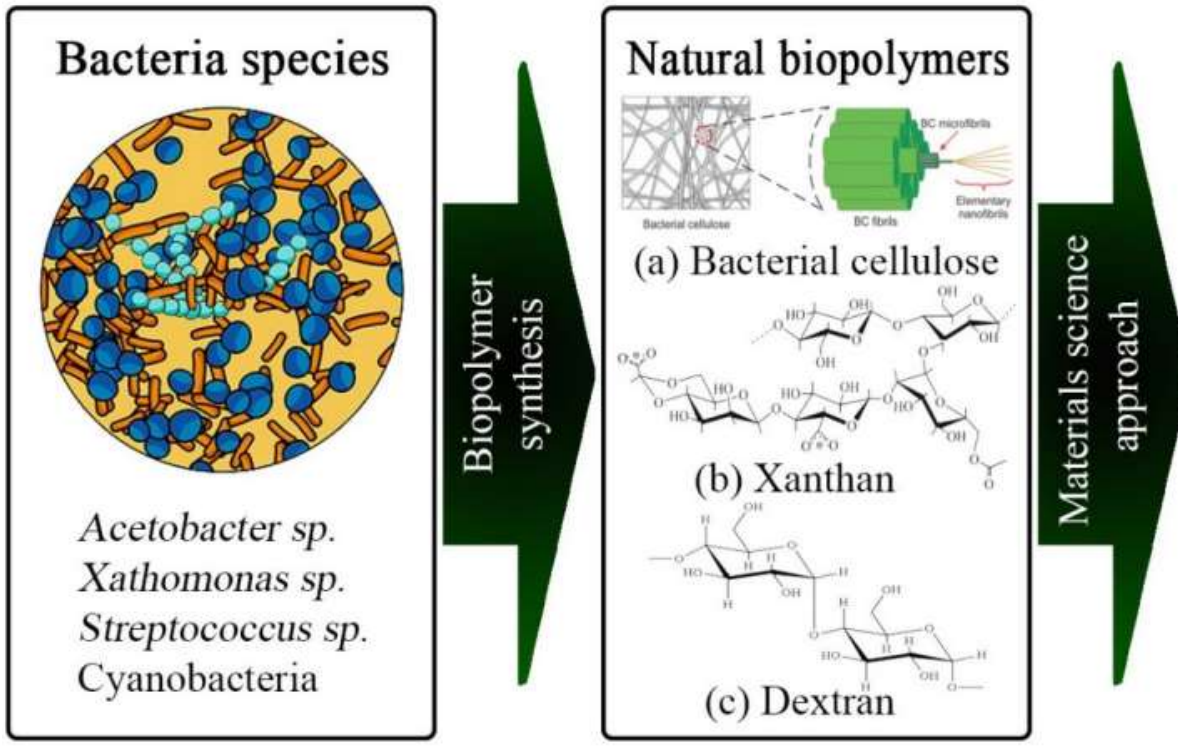

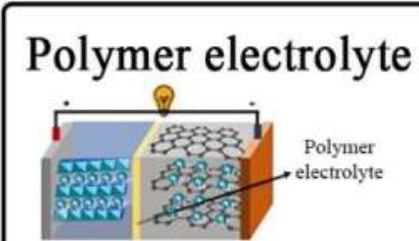

(d) Li-ion batteries

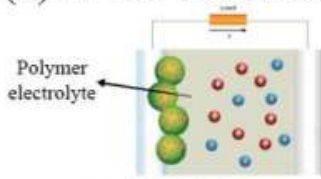

(e) DSSC

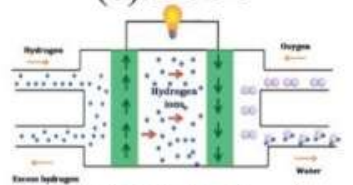

(f) PEM fuel cell

Figure 1. Schematic representation of the bacterial-polymer-based electrolytes. (a) Hierarchical structure of cellulose fibrils. Reproduced with permission from ref 64. Copyright 2019 Elsevier. (b) Structure of xanthan and (c) structure of dextran. Reproduced with permission from ref 65. Copyright 2019 Elsevier. (d) Schematic of lithium-ion batteries. Reproduced with permission from ref 66. Copyright 2019 Elsevier. (e) Schematic of a dye-sensitized solar cell (DSSC). Reproduced with permission from ref 21. Copyright 2016 Elsevier (f) Schematic of the proton exchange membrane (PEM) fuel cell. Reproduced with permission from ref 67. Copyright 2018 Elsevier.

case of bacterial cellulose (BC), which is naturally synthesized as an entangled network of cellulose nanofibers. $\mathrm{Xu}$ et al. prepared a gel polymer electrolyte with superior mechanical strength, incorporating lithium hexafluorophosphate into a $\mathrm{BC}$ network. $^{52}$

2.2.3. Plasticizer. Plasticizers are low-molecular-weight chemicals that contribute to the plasticity and flexibility of the polymeric material by lowering their glass transition temperature. ${ }^{53}$ Plasticizers also facilitate the ionic mobility across the polymer electrolytes, which translates in higher ionic conductivity. ${ }^{54}$ Multiple plasticizers have been employed to develop polymer electrolytes, including dimethyl carbonate, diocthyl adipate, dibutyl phthalate, propylene carbonate, and glycerol, among others. ${ }^{21}$ Neto et al. used glycerol as a plasticizer in conjunction with erbium salts and ionic liquids for the preparation of a gellan gum polymer electrolyte with good thermal stability. ${ }^{55}$ Tavares et al. opted for ethylene glycol as a plasticizer in a xanthan-based polymer electrolyte. ${ }^{51}$ It was noted that the plasticizer decreased the degree of crystallinity, thus improving the ionic conductivity.

2.2.4. Ionic Liquids. Ionic liquids (ILs) are low-temperature molten salts usually displaying organic cations and inorganic anions. ${ }^{56}$ Most salts require high temperatures to achieve this due to their relatively high melting point. However, several ionic liquids are able to remain in the liquid state at room temperature. ${ }^{57}$ These are called room-temperature ionic liquids (RTILs) and are actively applied for the fabrication of highperformance polymer electrolytes as the source of charge carriers. Favorable properties of RTILs are their electrochemical stability window, good ionic conductivity, nonvolatility, and low flammability. ${ }^{58,59}$ RTILs are usually added to the polymeric mixture before casting or by immersion. Some RTILs previously used in biopolymer-based electrolytes are 1butyl-3-methylimidazolium iodide, $N$-methyl- $N$-propylpyrrole bistrifluoromethanesulfonimide, methyl-trioctylammonium bis(trifluoromethyl sulfonyl)imide, and 1-methyl-3-propyl imidazolium iodide, among others. ${ }^{60-63}$

\section{BACTERIAL-POLYMER-BASED ELECTROLYTES}

Many types of bacteria are able to synthesize biopolymers. Through a materials science approach, the properties of bacterial biopolymers are improved to develop polymer electrolytes in either solid or gel state. Figure 1 illustrates certain types of biopolymer-producing bacteria species, the structures of the most commercially available bacterial polymers, namely, bacterial cellulose, xanthan, and DEX, and the potential application of such polymers in electrochemical devices, such as lithium-ion batteries, dye-sensitized solar cells, and polymer membrane fuel cells. In this section, the recent progress of polymer electrolytes based on different types of bacterial polymers is summarized. A comprehensive list of recently reported bacterial-polymer-based electrolytes is shown in Table S1 (Supporting Information).

3.1. Polysaccharides. 3.1.1. Bacterial Cellulose. BC is synthesized by some types of bacteria, such as Acetobacter sp. ${ }^{68}$ In the $\mathrm{BC}$ synthesis, the polymerization of glucose into $\beta-1,4-$ glucan chains occurs. ${ }^{69}$ BC is composed of a hierarchical structure of cellulose fibrils, which are subsequently composed of micro- and nanofibrils that form a coherent 3D network with remarkable mechanical properties (Figure 1a). ${ }^{64,70} \mathrm{BC}$ has enormous potential for a diversity of applications, including polymer electrolytes. ${ }^{52,71,72}$

$\mathrm{BC}$ is the most studied bacterial polymer for electrolyte applications. Multiplied approaches have been carried out to maximize the ionic conductivity of $\mathrm{BC}$ electrolytes in both solid and gel states. Torres et al. investigated the conductivity of BC films reinforced with reduced graphene oxide (RGO) and doped with $\mathrm{NH}_{4} \mathrm{I}^{73}$ The optimized film with 5 wt $\% \mathrm{NH}_{4} \mathrm{I}$ reached $1.32 \times 10^{-4} \mathrm{~S} \mathrm{~cm}^{-1}$ at room temperature. The $\mathrm{BC}-$ RGO film reached an outstanding tensile strength of 121.7 $\mathrm{MPa}$ (Figure 2). ${ }^{74}$ Gadim et al. developed Nafion-BC polymer electrolyte membranes for fuel cells. ${ }^{75}$ The composite membranes were prepared with a composition of 50 wt \% Nafion and 50 wt \% BC and exhibited in-plane protonic 


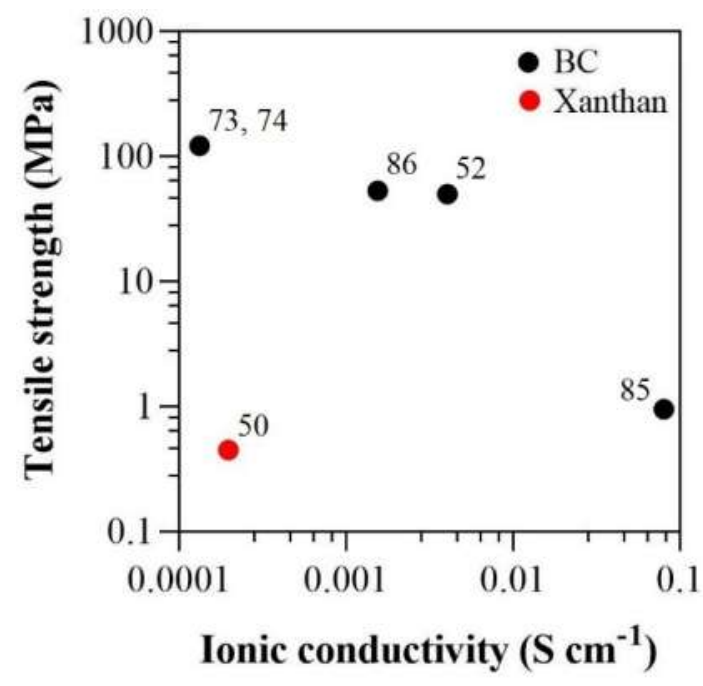

Figure 2. Ionic conductivity (room temperature) versus tensile strength in bacterial polymer electrolytes. The labels indicate the references. conductivity that varied depending on the temperature and relative humidity $(\mathrm{RH})$. At $98 \% \mathrm{RH}$ and $94{ }^{\circ} \mathrm{C}$, the protonic conductivity reached $0.14 \mathrm{~S} \mathrm{~cm}^{-1}$. Gadim et al. also investigated a BC-poly(4-styrene sulfonic acid) (PSSA) nanocomposite, reaching a similar protonic conductivity as the previous Nafion-BC $\left(0.1 \mathrm{~S} \mathrm{~cm}^{-1}\right)$ at the same $\mathrm{RH}$ and temperature. $^{76,77}$ Under similar environmental parameters, Vilela et al. reported the protonic conductivity of $\mathrm{BC}-$ poly(bis[2-(methacryloyloxy)ethyl] phosphate) $[\mathrm{P}($ bisMEP $)]$ and $\mathrm{BC}-$ fucoidan polymer electrolyte membranes to be 0.03 and $1.6 \times 10^{-3} \mathrm{~S} \mathrm{~cm}^{-1}$, respectively. ${ }^{15,78}$ The relatively low protonic conductivity of the $\mathrm{BC}$-fucoidan membrane elucidates the need for a source of charge carriers, such as salts or RTIL.

Gel polymer electrolytes are also suitable for electrochemical applications. ${ }^{79}$ Several studies investigated the performance of BC hydrogel polymer electrolytes. Zhang et al. prepared a $\mathrm{BC}-\mathrm{KOH}-\mathrm{KI}$ hydrogel with outstanding mechanical strength (2.1. $\mathrm{MPa})$ and ionic conductivity $\left(54 \times 10^{-3} \mathrm{~S} \mathrm{~cm}^{-1}\right) .{ }^{80}$ Fei et al. synthesized a BC-poly(acrylic acid) (PAA) hydrogel polymer electrolyte soaked in $1 \mathrm{M} \mathrm{Na} \mathrm{SO}_{4}$ that exhibited $0.06 \mathrm{~S} \mathrm{~cm}^{-1}$ of ionic conductivity at room temperature. ${ }^{81}$ Kotatha et al. synthesized a multiple-polysaccharide composite
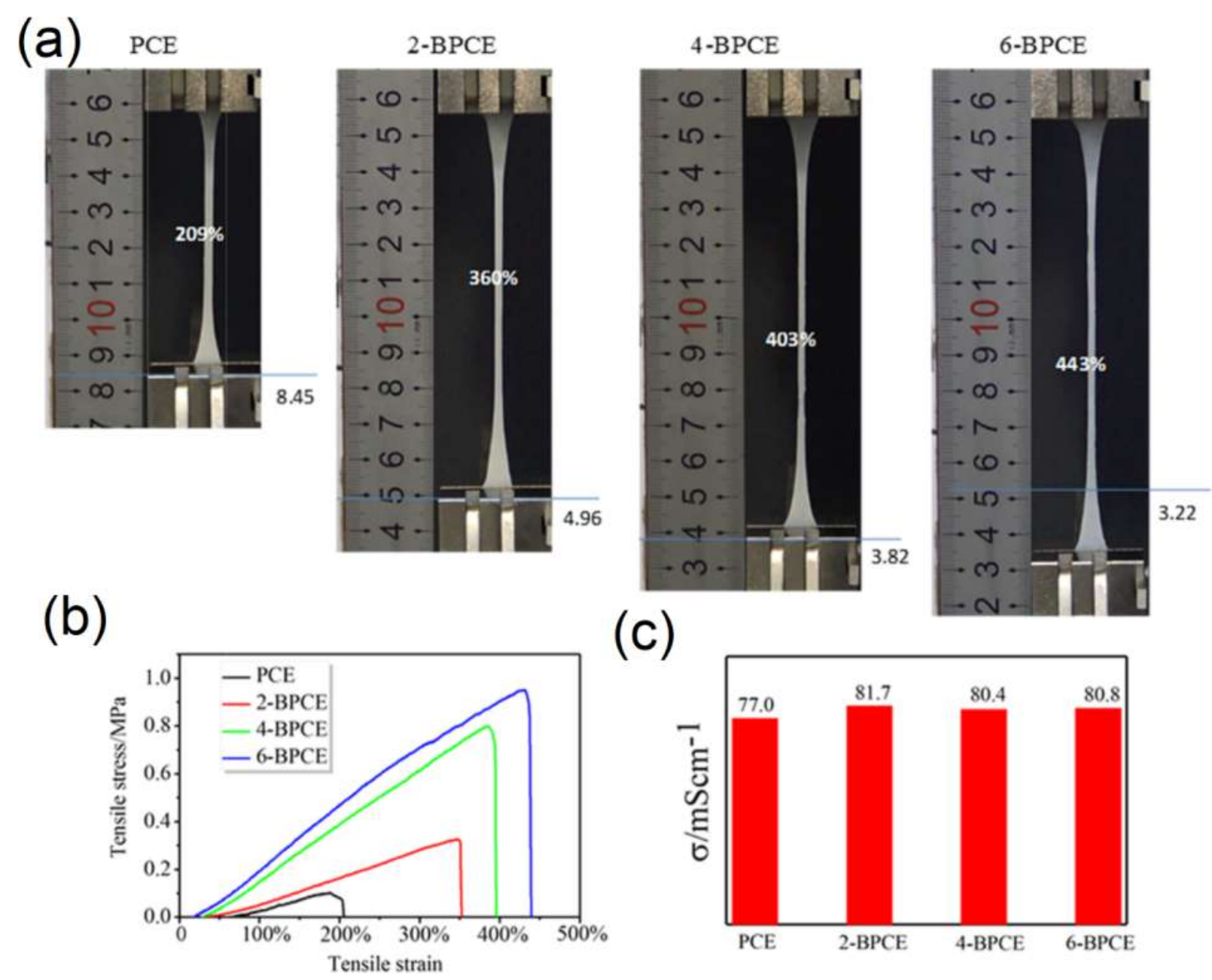

(c)

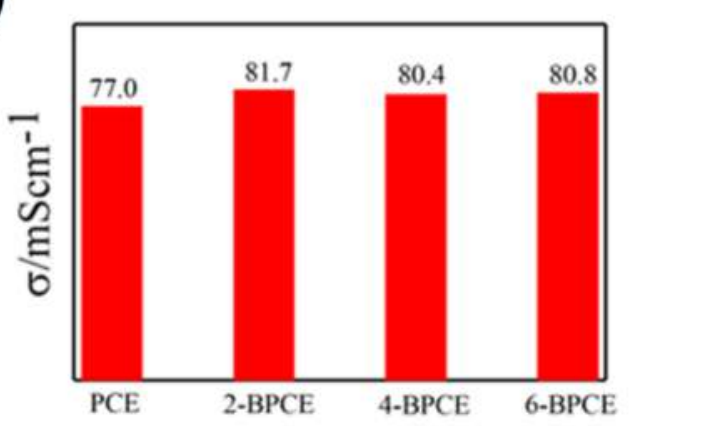

Figure 3. (a) Photographs showing the elongation of the BC/PVA composite hydrogel electrolytes (BPCE) prepared by Zhao et al. ${ }^{85}$ (b) The stress-strain curves show that 6-BPCE composite hydrogels had a tensile strength $\sim 9$ times higher than that of hydrogels of pure PVA (PCE). (c) Ionic conductivity of the hydrogel electrolytes. PCE, 2-BPCE, 4-BPCE, and 6-BPCE indicate 0, 2, 4, and 6 wt \% concentrations of BC, respectively. Reproduced with permission from ref 85. Copyright 2019 American Chemical Society. 


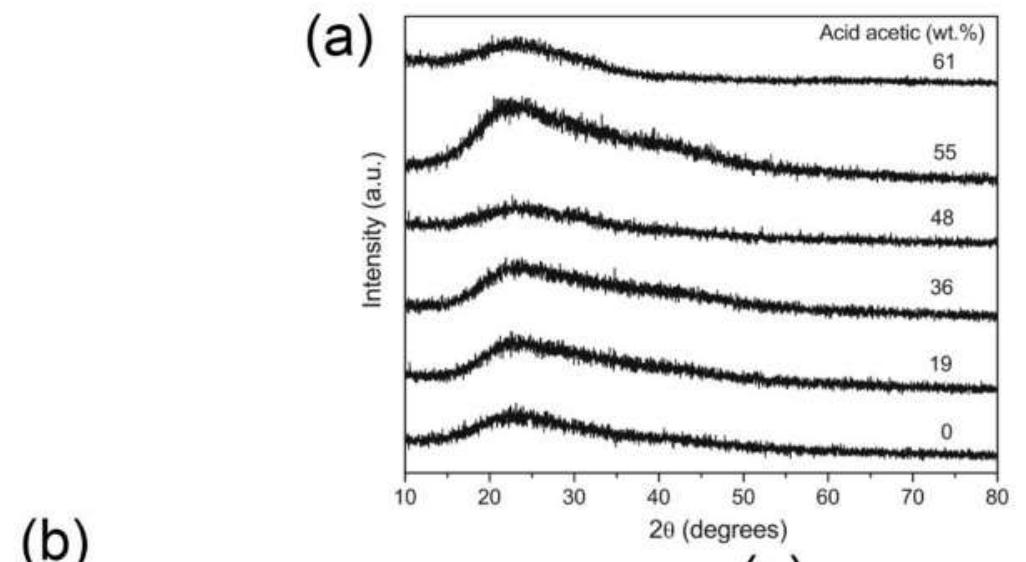

(b)

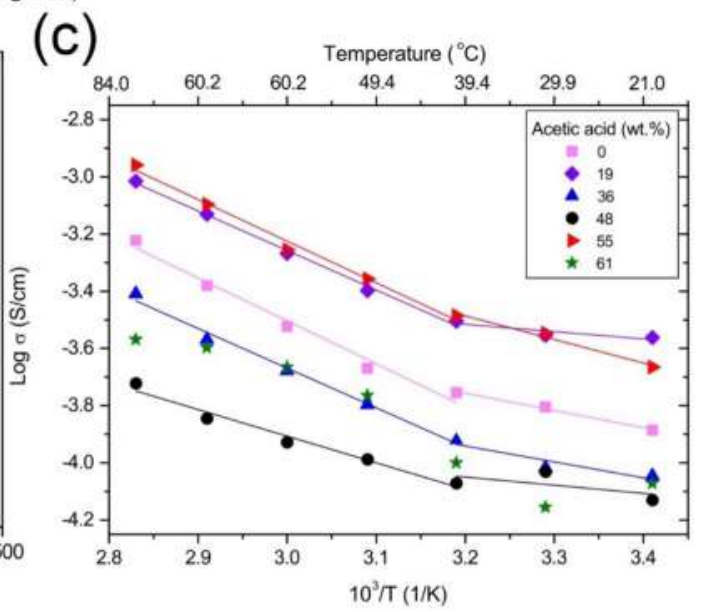

Figure 4. (a) XRD diffractograms of xanthan-PVA electrolytes with different AA concentrations. (b) Tensile stress vs elongation behavior of pure PVA and xanthan-PVA membrane. (c) Log of the conductivity as a function of temperature at different AA concentrations. Reproduced with permission from ref 50. Copyright 2018 Springer-Verlag.

consisting of $\mathrm{KIO}_{4}$-oxidized $\mathrm{BC}$ gel coated with chitosan (CTS) and alginate (ALG). ${ }^{82}$ The optimized CTS/ALG content enhanced the tensile strength $(8.96 \mathrm{~N})$ of the composite. However, the elongation at break was slightly reduced compared to pure $\mathrm{BC}$ (from 42.2 to $39.5 \%$ ). Yue et al. modified $\mathrm{BC}$ by sulfonation and fabricated a sulfonated $\mathrm{BC}$ (SBC)-polyaniline (PANI) gel polymer electrolyte. ${ }^{4}$ Importantly, ionic conductivity was associated with the degree of sulfonation, reaching $5.2 \times 10^{-3} \mathrm{~S} \mathrm{~cm}^{-1}$. The degree of sulfonation gives free sulfonic groups that bond to water molecules in hydronium form and serve as proton carriers. Protons hopping through the water-filled highly porous network result in faster transport of charges, thus increasing the protonic conductivity. ${ }^{4,83,84}$ Zhao et al. fabricated highly flexible hydrogel electrolytes based on $\mathrm{BC}$ and poly(vinyl alcohol) (PVA) with $\mathrm{KOH}$ and $\mathrm{Zn}\left(\mathrm{CH}_{3} \mathrm{COO}\right)_{2}$ solutions. $^{85}$ Apart from the high ionic conductivity of $0.08 \mathrm{~S} \mathrm{~cm}^{-1}$, the tensile strength $(0.951 \mathrm{MPa})$ was $\sim 9$ times higher than that of pure PVA (Figure 3). Xu et al. developed a gel polymer electrolyte based on BC cross-linked by a fast freeze-drying method. ${ }^{52}$ The gel had a conductivity of $4.04 \times 10^{-3} \mathrm{~S} \mathrm{~cm}^{-1}$ and a tensile strength of $49.9 \mathrm{MPa}$. Ding et al. synthesized a composite aerogel electrolyte consisting of $\mathrm{BC}$ and $\mathrm{Li}_{0.33} \mathrm{La}_{0.557} \mathrm{TiO}_{3}$ nanowires. ${ }^{86}$ The aerogel exhibited $1.54 \times$ $10^{-3} \mathrm{~S} \mathrm{~cm}^{-1}$ of ionic conductivity and $\sim 53 \mathrm{MPa}$ of tensile strength. Lastly, Yan et al. prepared a quasi-solid electrolyte based on BC with a solution of lithium bis(trifluoromethanesulfonyl)imide (LiTFSI) and $N$-methyl- $N$ - propylpyrrole bistrifluoromethanesulfonimide salt ([Py13][TFSI]) RTILs reaching a maximum conductivity of $2.38 \times$ $10^{-4} \mathrm{~S} \mathrm{~cm}^{-1}$ at room temperature. ${ }^{61}$

$\mathrm{BC}$ has also been used as reinforcement in other biobased polymer electrolytes. Fei et al. developed PAA-sodium alginate hydrogel polymer electrolyte chemically cross-linked by poly(ethylene glycol) diacrylate (PEGDA) and $\mathrm{Ca}^{2+}$ and reinforced with $\mathrm{BC} .^{49}$ The hydrogel showed an ionic conductivity of $0.035 \mathrm{~S} \mathrm{~cm}^{-1}$. Yang et al. fabricated a BCreinforced poly(methyl vinyl ether-alt-maleic anhydride) (P(MVE-alt-MA)) and triethyl phosphate/vinylene carbonate/sodium perchlorate $\left(\mathrm{TEP} / \mathrm{VC} / \mathrm{NaClO}_{4}\right)$ as plasticizer. ${ }^{72}$ Although the hydrogel demonstrated a relatively low ionic conductivity $\left(2.2 \times 10^{-4} \mathrm{~S} \mathrm{~cm}^{-1}\right)$, the composition enabled superior flame retardancy behavior.

3.1.2. Xanthan. Xanthan is a high-molecular-weight exopolysaccharide produced by Xanthomonas bacteria. ${ }^{87}$ Its structure consists of a $\beta$-1,4-linked D-glucose backbone and a trisaccharide side chain consisting of $\beta$-D-mannose- $(1,4)-\beta$-Dglucuronic acid- $(1,2)-\alpha$-D-mannose. ${ }^{88,89}$ Although xanthan is a well-established product in the food industry, other applications include biomedical, drug delivery, oil recovery, and polymer electrolytes. $^{87,90-93}$

Pawlicka et al. prepared xanthan-acetic acid (AA) polymer electrolytes with ethylene glycol and glutaraldehyde as a plasticizer and cross-linking agent, respectively. ${ }^{51,94}$ The resulting ionic conductivity reached $7.26 \times 10^{-5} \mathrm{~S} \mathrm{~cm}^{-1}$. A similar approach was carried out by Caldeira et al., fabricating 
(a)

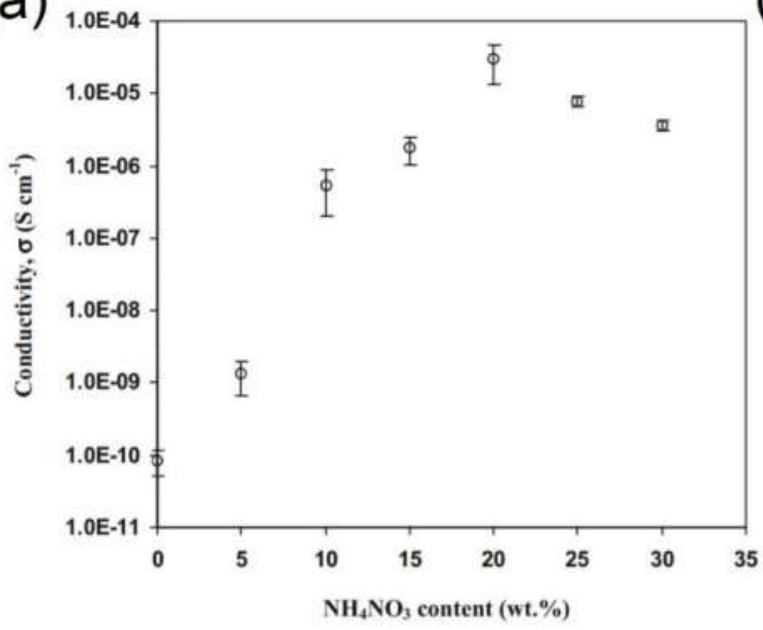

(b)

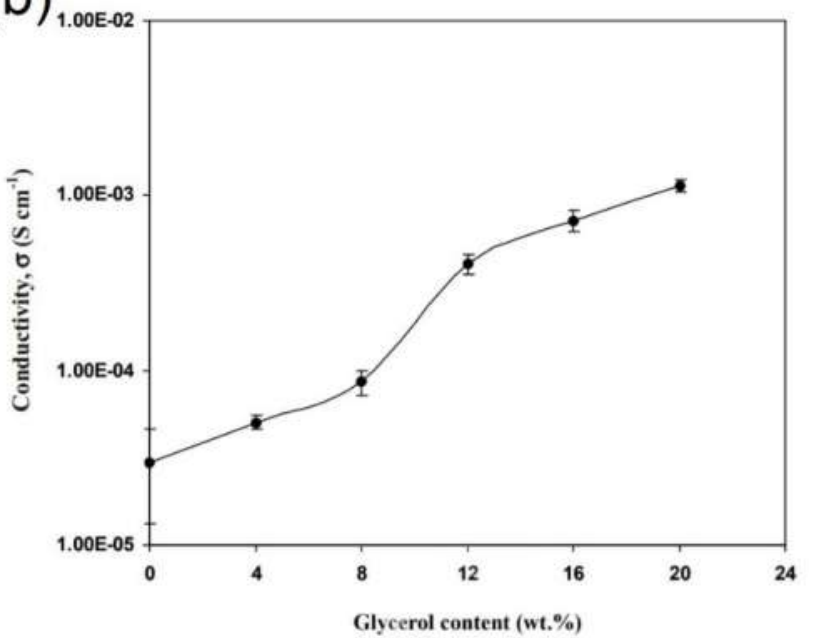

Figure 5. (a) Ionic conductivity versus $\mathrm{NH}_{4} \mathrm{NO}_{3}$ content of DEX-based electrolytes. Reproduced with permission from ref 106 . Copyright 2019 Springer-Verlag. (b) Ionic conductivity versus glycerol content in $20 \mathrm{wt} \% \mathrm{NH}_{4} \mathrm{NO}_{3}$ DEX-based electrolyte. Reproduced with permission from ref 107. Copyright 2020 Elsevier.

xanthan-PVA polymer electrolytes with AA, glycol, and formaldehyde as the plasticizers and cross-linking agent, respectively (Figure $4 \mathrm{a}) .^{50} \mathrm{X}$-ray diffraction analysis revealed a large halo at $2 \theta=24^{\circ}$ at any AA concentration (Figure $4 \mathrm{~b}$ ), which indicated a predominant amorphous phase. Moreover, the addition of xanthan to PVA increases the overall flexibility of the membrane (Figure 4c). However, the ionic conductivity remained relatively low $\left(1.94 \times 10^{-4} \mathrm{~S} \mathrm{~cm}^{-1}\right)$ at room temperature (Figure 4d).

Several studies have reported the use of strong bases or acids as a source of charge carriers. Di Palma et al. developed a simple alkaline xanthan-based hydrogel soaked in $8 \mathrm{M} \mathrm{KOH}$, which exhibited an excellent ionic conductivity of $8.8 \times 10^{-2} \mathrm{~S}$ $\mathrm{cm}^{-1} .^{95}$ In a later study, Di Palma et al. selected $\mathrm{HCl}$ instead of $\mathrm{KOH}$ as the source of free ions, which exhibited $3.6 \times 10^{-2} \mathrm{~S}$ $\mathrm{cm}^{-1}$ of ionic conductivity at $5 \mathrm{M} \mathrm{HCl} .^{92,93,96}$ Similarly, Sharma et al. prepared a xanthan hydrogel doped with $0.015 \mathrm{M}$ $\mathrm{NaOH}$ that demonstrated an ionic conductivity of $4.71 \times 10^{-3}$ $\mathrm{S} \mathrm{cm}{ }^{-1} \cdot{ }^{97}$ Zhang et al. synthesized a xanthan gel electrolyte with sulfate salts. ${ }^{98}$ The gel was composed of $3 \mathrm{M} \mathrm{ZnSO}_{4}$ and $0.1 \mathrm{M} \mathrm{MnSO}_{4}$ dissolved in $20 \mathrm{wt} \%$ xanthan polymer host and exhibited $1.65 \times 10^{-2} \mathrm{~S} \mathrm{~cm}^{-1}$ of conductivity. In the same line as their previous research, $\mathrm{Yu}$ et al. prepared a xanthan-based electrolyte with $1 \mathrm{M} \mathrm{Na}_{2} \mathrm{SO}_{4}$ as the sulfate salt that exhibited an excellent conductivity of $1.12 \times 10^{-2} \mathrm{~S} \mathrm{~cm}^{-1} .^{99}$ Lastly, Soni et al. prepared a xanthan gel in $1 \mathrm{M} \mathrm{H}_{2} \mathrm{SO}_{4}{ }^{100}$ The conductivity of the electrolyte is not mentioned, but the assembly and performance of a supercapacitor using the xanthan electrolyte are reported.

3.1.3. Dextran. DEX is composed of $\alpha$-1,6-linked $\alpha$-Dglucose backbone and the initial end of the branch chain linked by $\alpha(1,4)$ or $\alpha(1,3)$ glycosidic bonds. ${ }^{101}$ Species of the Leuconostoc and Streptococcus genus are the main producers of DEX. ${ }^{19}$ Its high water solubility, biodegradability, and biocompatibility make DEX suited for applications in the food industry, drug delivery media, and biomaterials. ${ }^{102-104}$

The studies investigating DEX-based electrolytes are mainly focused on electrolytes suited for supercapacitors. Hamsan et al., Aziz et al., and Kadir et al. conducted a series of studies investigating the electrical response of pure DEX, blends, and different ammonium salts. For instance, pure DEX doped with 20 wt $\% \mathrm{NH}_{4} \mathrm{Br}$ or 20 wt $\% \mathrm{NH}_{4} \mathrm{NO}_{3}$ demonstrated a relatively low ionic conductivity, reaching $3.00 \times 10^{-5}$ and $1.67 \times 10^{-6} \mathrm{~S}$ $\mathrm{cm}^{-1}$, respectively. ${ }^{105,106}$ However, the addition of $20 \mathrm{wt} \%$ glycerol to the $\mathrm{DEX}-\mathrm{NH}_{4} \mathrm{NO}_{3}$ electrolyte increased the conductivity to up to $1.15 \times 10^{-3} \mathrm{~S} \mathrm{~cm}^{-1}$ (Figure 5). ${ }^{107}$ The incorporation of ammonium salts to polymer blends showed a better performance than pure DEX as a polymer host. CTSDEX blend electrolytes doped with $\mathrm{NH}_{4} \mathrm{SCN}, \mathrm{NH}_{4} \mathrm{~F}$, and $\mathrm{NH}_{4} \mathrm{I}$ exhibited maximum ionic conductivities of $1.28 \times 10^{-4}$, $1.00 \times 10^{-3}$, and $5.16 \times 10^{-3} \mathrm{~S} \mathrm{~cm}^{-1}$, respectively. ${ }^{45,108,109}$ Interestingly, the CTS-DEX blend doped $\mathrm{LiClO}_{4}$ salt showed the same conductivity as with $\mathrm{NH}_{4} \mathrm{I}\left(5.16 \times 10^{-3} \mathrm{~S} \mathrm{~cm}^{-1}\right){ }^{44}$ On the other hand, a PVA-DEX blend doped with $\mathrm{NH}_{4} \mathrm{I}$ exhibited a relatively low conductivity of $2.08 \times 10^{-5} \mathrm{~S}$ $\mathrm{cm}^{-1} \cdot{ }^{110}$ Lastly, methylcellulose (MC)-DEX polymer blend doped with $\mathrm{NH}_{4} \mathrm{I}$ was reported to have a decent ionic conductivity of $1.12 \times 10^{-3} \mathrm{~S} \mathrm{~cm}^{-143}$.

3.1.4. Gellan. Gellan, also known as gellan gum, is a tetrasaccharide composed of two D-glucose, one L-rhamnose, and one D-glucuronic acid repeating units. ${ }^{111,112}$ It is mainly obtained from Sphingomonas elodea, although other Sphingomonas species can synthesize it. ${ }^{113,114}$ Gellan gum-based cell and drug delivery systems have been widely investigated, but not much effort has been devoted to the field of materials for electrochemical applications. ${ }^{113,115}$

Noor et al. fabricated gellan membrane electrolytes doped with $\mathrm{LiCF}_{3} \mathrm{SO}_{3}$ using a simple casting method. ${ }^{116}$ The highest ionic conductivity $\left(5.4 \times 10^{-4} \mathrm{~S} \mathrm{~cm}^{-1}\right)$ was observed at $40 \mathrm{wt}$ $\% \mathrm{LiCF}_{3} \mathrm{SO}_{3}$. The IR-deconvolution analysis demonstrated that ionic conductivity was directly associated with the percentage of free ions in the membrane (Figure 6). ${ }^{117}$ Concentrations of $\mathrm{LiCF}_{3} \mathrm{SO}_{3}$ higher than $40 \mathrm{wt} \%$ reduced the conductivity due to the decrease in the mobility of free ions. Halim et al. used LiI as the dopant for gellan-based electrolytes, exhibiting $3.8 \times 10^{-4} \mathrm{~S} \mathrm{~cm}^{-1}$ of ionic conductivity. ${ }^{118}$ By adding glycerol to the mixture, the ionic conductivity increased to $1.5 \times 10^{-3} \mathrm{~S} \mathrm{~cm}^{-1}$. Neto et al. cast gellan-based polymer electrolytes with $N, N, N$-trimethyl- $N$ - (2hydroxyethyl)ammonium bis(trifluoromethylsulfonyl)imide, 


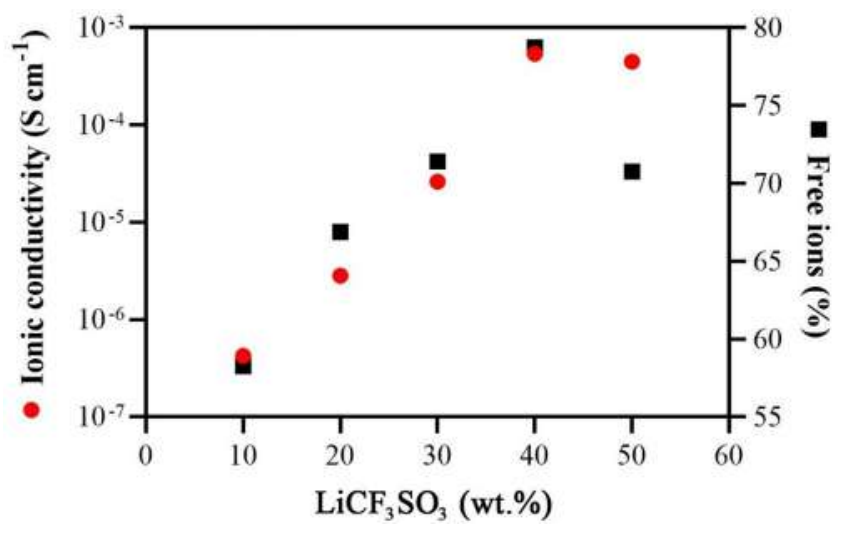

Figure 6. Ionic conductivity and percentage of free ions in the gellanbased electrolyte at different $\mathrm{LiCF}_{3} \mathrm{SO}_{3}$ concentrations. The graph was built using the data obtained from ref 117.

$\left[\mathrm{N}_{1112(\mathrm{OH})}\right]\left[\mathrm{NTf}_{2}\right]$, glycerol, and $\mathrm{Er}\left(\mathrm{CF}_{3} \mathrm{SO}_{3}\right)_{3}$ as the RTIL, plasticizer, and salt, respectively. ${ }^{55}$ Despite using multiple approaches, the maximum ionic conductivity reported was 5.21 $\times 10^{-6} \mathrm{~S} \mathrm{~cm}^{-1}$ at $30^{\circ} \mathrm{C}$. Singh et al. used KI salt (40 wt \%) in a simple casting method with gellan, which exhibited $2.5 \times 10^{-2}$ $\mathrm{S} \mathrm{cm}^{-1}$ conductivity. ${ }^{119}$ Lastly, Sudhakar et al. prepared boraxcross-linked gellan-based electrolytes with different acid dopants $\left(\mathrm{H}_{3} \mathrm{PO}_{4}, \mathrm{H}_{2} \mathrm{SO}_{4} \text {, and } \mathrm{HCl}\right)^{120}$ The maximum conductivity of $5.1 \times 10^{-3} \mathrm{~S} \mathrm{~cm}^{-1}$ was obtained by adding $\mathrm{H}_{3} \mathrm{PO}_{4}$ at $35{ }^{\circ} \mathrm{C}$.

3.1.5. Levan. Levan is a group of fructans differentiated by their $\beta(2,6)$ glycosidic bonds and laterally branched $\beta(2,1)$ bonds that are synthesized by many types of bacteria, such as Bacillus spp., Zymomonas spp., and Halomonas sp. ${ }^{121,122}$ Only one study investigated levan as the main component of solid electrolytes. Jo et al. developed a polymer electrolyte based on levan and choline and malate-based RTIL. ${ }^{123}$ The electrolyte served as a substrate for biocompatible organic transistors, which can be applied in implantable devices.
3.1.6. Other Polysaccharides. An early study by Annapurna et al. used the extracellular polysaccharides (EPS) as-produced by Rhizobium sp. isolated from Aeschynomene indica (L). ${ }^{124}$ Gas chromatography/mass spectrometry analysis of the EPS showed to be composed of derivatives of glucose, mannose, and pyranose. The EPS extract was cross-linked with sulfosuccinic acid (SSA) and cast into a solid membrane electrolyte, which exhibited proton conductivity ranging from 2.60 to $5.04 \times 10^{-3} \mathrm{~S} \mathrm{~cm}^{-1}$ at different temperatures (30-90 ${ }^{\circ} \mathrm{C}$ ). Gonzales et al. investigated the exopolysaccharide extracted from Nostoc commune cyanobacteria (NCP). ${ }^{125}$ This NCP can be used to prepare films with an amorphous structure. Ammonium salt $\mathrm{NH}_{4} \mathrm{I}$ and RTIL 1-butyl-3methylimidazolium chloride $([\mathrm{Bmim}] \mathrm{Cl})$ can be easily dissolved in NCP. The glass transition temperature $\left(T_{\mathrm{g}}\right)$ of NCP varied depending on the charge carriers used. The lowest $T_{\mathrm{g}}\left(-71.34{ }^{\circ} \mathrm{C}\right)$ was reached with the addition of RTIL. The broadband dielectric spectroscopy (BDS) tests performed confirmed that ion diffusion and polarization effects took place after the addition of ammonium salt and $[\mathrm{Bmim}] \mathrm{Cl}$. This suggested that NCP could be used for the preparation of polymer electrolytes.

3.2. Polyanhydrides. 3.2.1. Polyphosphates. Contrary to the bacterial polysaccharides previously described, polyphosphates are polyanhydrides constructed by polymerized phosphate $\left(\mathrm{PO}_{4}{ }^{3-}\right)$ units linked by phosphoanhydride bonds. ${ }^{126}$ It is an intracellular polymer synthesized by a wide range of organisms, including bacteria and archaea. ${ }^{19}$ The commercial applications of polyphosphates are in the field of fertilizers, water treatment, and food industry. ${ }^{18}$ Despite some studies displaying potential, polyphosphates as polymer electrolytes remain poorly investigated.

Iliescu et al. developed polyphosphoester (PPE) membrane electrolytes doped with $\mathrm{LiCF}_{3} \mathrm{SO}_{3}$ salt and cross-linked by tris(1,4-butanediolmonoacrylate) phosphate (TPA). The highest ionic conductivity reached $4.22 \times 10^{-6} \mathrm{~S} \mathrm{~cm}^{-1}$ at $20 \mathrm{wt} \%$ $\mathrm{LiCF}_{3} \mathrm{SO}_{3}$. Sun et al. investigated ammonium polyphosphate

Table 1. Electrochemical Properties of Metal-Ion Batteries Based on Bacterial Polymers

\begin{tabular}{|c|c|c|c|c|c|}
\hline battery type & electrolyte & discharge voltage $(\mathrm{V})$ & current density $\left(\mathrm{mA} \mathrm{cm}{ }^{-2}\right)$ & capacity $\left(\mathrm{mAh} \mathrm{g}^{-1}\right)$ & ref \\
\hline $\mathrm{Al}-$ air & $\begin{array}{l}\text { xanthan } \\
\mathrm{HCl}\end{array}$ & 0.9 & 3 & & 96 \\
\hline $\mathrm{Zn}$-air & $\begin{array}{l}\mathrm{BC}-\mathrm{PVA} \\
\mathrm{KOH} \\
\mathrm{Zn}-\left(\mathrm{CH}_{3} \mathrm{COO}\right)_{2}\end{array}$ & 1.24 & 0.5 & & 85 \\
\hline Li-ion & $\mathrm{BC}$ & $\sim 0.42$ & 0.5 & 141.2 & 52 \\
\hline $\mathrm{Zn}$-air & $\begin{array}{l}\mathrm{BC} \\
\mathrm{KOH} \\
\mathrm{KI}\end{array}$ & 0.46 & 5 & 794 & 80 \\
\hline Li-ion & $\begin{array}{l}\text { BC } \\
\text { LiTFSI } \\
{[\text { Py13][TFSI }]}\end{array}$ & & & 138.4 & 61 \\
\hline Zn-ion & $\begin{array}{l}\text { xanthan } \\
\mathrm{ZnSO}_{4} / \mathrm{MnSO}_{4}\end{array}$ & 1.8 & 0.15 & 260 & 98 \\
\hline $\mathrm{Al}$-air & $\begin{array}{l}\text { xanthan } \\
\mathrm{KOH}\end{array}$ & 1 & 3 & & 93 \\
\hline Li-ion & $\begin{array}{l}\mathrm{P} 3 \mathrm{HB}-3 \mathrm{HV} \\
\mathrm{EC} / \mathrm{DEC} / \mathrm{LiPF}_{6}\end{array}$ & & & 100 & 133 \\
\hline Li-ion & $\begin{array}{l}\mathrm{Li}_{0.33} \mathrm{La}_{0.557} \mathrm{TiO}_{3} \\
\text { nanowires } \\
\mathrm{BC}\end{array}$ & & & 151.7 & 86 \\
\hline
\end{tabular}


Table 2. Performance Comparison of Supercapacitors Based on Bacterial Polymer Electrolytes ${ }^{a}$

\begin{tabular}{|c|c|c|c|c|c|}
\hline electrolyte & $\sigma\left(\mathrm{S} \mathrm{cm}^{-1}\right)$ & $C_{\mathrm{s}}\left(\mathrm{F} \mathrm{g}^{-1}\right)$ - scan rate $\left(\mathrm{mV} \mathrm{s}^{-1}\right)$ & $\eta$ - \# of cycles & $E_{\mathrm{d}}\left(\mathrm{Wh} \mathrm{kg}^{-1}\right)$ & ref \\
\hline $\begin{array}{l}\text { CTS-DEX blend } \\
\mathrm{LiClO}_{4}\end{array}$ & $5.16 \times 10^{-3}$ & $8.70-10$ & $92 \%-100$ & 0.86 & 44 \\
\hline $\begin{array}{l}\text { borax-gellan } \\
\mathrm{H}_{3} \mathrm{PO}_{4}\end{array}$ & $5.1 \times 10^{-3}$ & $146-2$ & $95 \%-1000$ & 9 & 120 \\
\hline $\begin{array}{l}\text { PVA-DEX blend } \\
\mathrm{NH}_{4} \mathrm{I}\end{array}$ & $2.08 \times 10^{-5}$ & $4.20-50$ & & 0.55 & 110 \\
\hline $\begin{array}{l}\text { CTS-DEX blend } \\
\mathrm{NH}_{4} \mathrm{I}\end{array}$ & $5.16 \times 10^{-3}$ & $19.1-100$ & & 3.1 & 108 \\
\hline $\begin{array}{l}\text { CTS-DEX blend } \\
\mathrm{NH}_{4} \mathrm{~F}\end{array}$ & $1.00 \times 10^{-3}$ & $12.4-100$ & & 1.4 & 109 \\
\hline $\begin{array}{l}\mathrm{MC}-\mathrm{DEX} \text { blend } \\
\mathrm{NH}_{4} \mathrm{I}\end{array}$ & $1.12 \times 10^{-3}$ & $55-100$ & & 6.3 & 43 \\
\hline $\begin{array}{l}\mathrm{DEX} \\
\mathrm{NH}_{4} \mathrm{Br}\end{array}$ & $1.67 \times 10^{-6}$ & $1.61-50$ & & & 105 \\
\hline $\begin{array}{l}\mathrm{DEX} \\
\mathrm{NH}_{4} \mathrm{NO}_{3} \\
\text { glycerol }\end{array}$ & $1.15 \times 10^{-3}$ & $15.7-0.5$ & $92 \%-1000$ & 1.57 & 107 \\
\hline
\end{tabular}

$\left(\mathrm{NH}_{4} \mathrm{PO}_{3}\right)$ as polymer electrolyte for intermediate temperature fuel cells (ITFCs). ${ }^{127}$ The ionic conductivity ranged from 2.2 $\times 10^{-5}$ to $2.69 \times 10^{-3} \mathrm{~S} \mathrm{~cm}^{-1}$ depending on the temperature (ranging from 50 to $275{ }^{\circ} \mathrm{C}$ ). Despite exhibiting a relatively low conductivity at low temperatures, ITFCs normally operate at $>150{ }^{\circ} \mathrm{C}$, which makes $\mathrm{NH}_{4} \mathrm{PO}_{3}$ suitable for this application. An earlier study by Kluy et al. demonstrated similar results. They fabricated an ammonium polyphosphate $-\mathrm{SiO}_{2}-\mathrm{TiO}_{2}$ composite for ITFCs, which exhibited $\sim 2.4 \times 10^{-3} \mathrm{~S} \mathrm{~cm}^{-1}$ at $200{ }^{\circ} \mathrm{C} .{ }^{128}$ Lastly, Skovroinski et al. synthesized an aluminum/ion polyphosphate metallo-gel that exhibited a conductivity of $1.72 \times 10^{-2} \mathrm{~S} \mathrm{~cm}^{-1}$. ${ }^{129}$ The metallo-gel also exhibited fast self-healing properties, which are desirable for flexible and long-lasting devices.

3.3. Polyesters. 3.3.1. Polyhydroxyalkanoates. Polyhydroxyalkanoates (PHAs) are produced by many bacterial species and are regarded for their biodegradability, biocompatibility, and thermoplastic properties. ${ }^{130,131}$ PHAs are suggested to be a worthy candidate for replacing fossil-fuel-based plastics. ${ }^{132}$ Dall'Asta et al. developed a PHA-based gel polymer electrolyte aimed for lithium-ion batteries. ${ }^{133}$ The bacterial PHAs applied consisted of the biopolymers poly(3-hydroxybutyrate) (P3HB) and poly(3-hydroxybutyrate-co-3-hydroxyvalerate) ( $\mathrm{P} 3 \mathrm{HB}-3 \mathrm{HV})$ gelled with commercial liquid electrolyte $\mathrm{EC} / \mathrm{DEC} / \mathrm{LiPF}_{6}$. The gel polymer electrolyte exhibited $0.8 \times 10^{-3} \mathrm{~S} \mathrm{~cm}^{-1}$ of ionic conductivity. The biodegradation test indicated that $\mathrm{PHB}-\mathrm{HV}$ is readily biodegradable in water ( $75 \pm 5 \%$ biodegradation value after 28 days). Hazwan Hussin et al. used the biopolymer poly(3hydroxybutyrate-co-3-hydroxyhexanoate) ( $\mathrm{P} 3 \mathrm{HB}-3 \mathrm{HHx})$ produced by Cupriavidus necator Re2058/pCB113 filled with nanocrystalline cellulose and added glycerol and $\mathrm{LiClO}_{4} \cdot{ }^{134} \mathrm{At}$ the highest concentration of $\mathrm{LiClO}_{4}$ (40 wt \%), the polymer electrolyte showed the highest conductivity of $1.56 \times 10^{-4} \mathrm{~S}$ $\mathrm{cm}^{-1}$.

\section{APPLICATIONS}

4.1. Batteries. Batteries may be the most successful and widespread electricity storage systems. ${ }^{135}$ The introduction of lithium-ion batteries in 1991 revolutionized the industry of portable electronic devices. ${ }^{136}$ Owing to their extensive use worldwide, secondary batteries pose safety issues and environmental hazards that need to be addressed. ${ }^{137}$ Several studies investigated the application of bacterial-polymer-based electrolytes in metal-ion batteries as a novel biocomponent (Table 1). For instance, Zhang et al. prepared flexible $\mathrm{Zn}$-air batteries based on $\mathrm{BC}$ hydrogel electrolytes soaked in $\mathrm{KOH}$ and $\mathrm{KI}, \mathrm{Zn}$ foil anode, and carbon cloth loaded with a catalyst as the cathode. ${ }^{80}$ The battery demonstrated a capacity of $794 \mathrm{mAh}$ $\mathrm{g}^{-1}$ at $10 \mathrm{~mA} \mathrm{~cm} \mathrm{~cm}^{-2}$ of current density, along with great flexibility and stable open-circuit voltage at various bending angles. Notably, Zhang et al. developed a high-performance $\mathrm{Zn}$-ion battery composed of high ionic conductivity $(1.46 \times$ $10^{-2} \mathrm{~S} \mathrm{~cm}^{-1}$ ) xanthan-based electrolyte doped with $\mathrm{ZnSO}_{4} /$ $\mathrm{MnSO}_{4}, \mathrm{MnO}_{2} / \mathrm{CNT}$ cathode, and $\mathrm{Zn}$ anode. The battery demonstrated a capacity of $260 \mathrm{mAh} \mathrm{g}^{-1}$ at $1 \mathrm{C}$ and about 1.8 $\mathrm{V}$ of discharge voltage. Regarding cyclability, the Coulombic efficiency remained at 100 and $90 \%$ capacity retention after over 330 cycles. After 1000 cycles, the capacity was limited to $127 \mathrm{mAg} \mathrm{g}^{-1}$. Importantly, xathan gum-based electrolytes slow down self-corrosion and limit the formation of zinc dendrite. Zinc dendrites are a well-known problem in $\mathrm{Zn}$-ion batteries that cause internal short circuits. ${ }^{138}$ Indeed, xanthan serves as a promising material for polymer electrolytes in competitive high-performance $\mathrm{Zn}$-ion batteries with properties that reduce corrosion and avoid the growth of zinc dendrite. $\mathrm{Xu}$ et al. developed Li-ion batteries based on cross-linked BC polymer electrolytes with $\mathrm{LiFePO}_{4}$ cathodes and $\mathrm{Li}$ anodes. ${ }^{52}$ The discharge voltage reached about $0.42 \mathrm{~V}$ and a discharge capacity of $141.2 \mathrm{mAh} \mathrm{g}^{-1}$. Like xanthan electrolytes in $\mathrm{Zn}$-ion batteries, the cross-linking process increases the mechanical strength of the gel polymer electrolyte, which suppresses the occurrence of lithium dendrite. ${ }^{139}$ Yan et al. prepared Li-ion batteries using BC-LiTFSI-[Py13][TFSI] electrolytes, LiFe$\mathrm{PO}_{4}$ cathodes, and $\mathrm{Li}$ anodes. ${ }^{61}$ The assembled cell showed a capacity of $138 \mathrm{mAh} \mathrm{g}^{-1}$ that remained almost constant after 100 cycles at 0.1 C. Ding et al. used compressed BC$\mathrm{Li}_{0.33} \mathrm{La}_{0.557} \mathrm{TiO}_{3} \mathrm{NW}$ aerogels as electrolytes in Li-ion batteries. The battery cell maintained its electrical performance even after $1200 \mathrm{~h}$ at high current density $\left(5 \mathrm{~mA} \mathrm{~cm}^{-2}\right)$.

4.2. Supercapacitors. Supercapacitors are attractive energy storage components for several portable electronic 
(a)

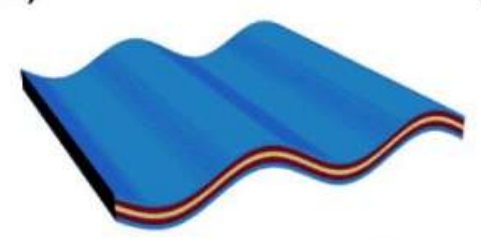

All-solid-state supercapacitors

(d)

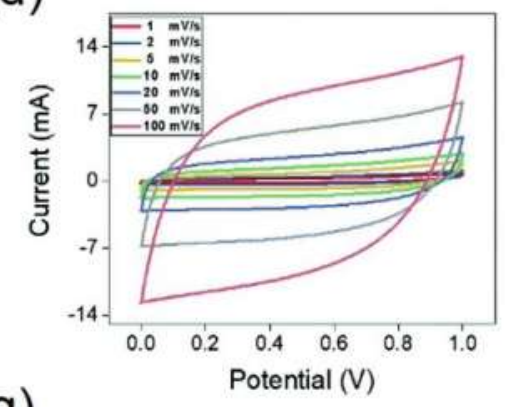

(g)
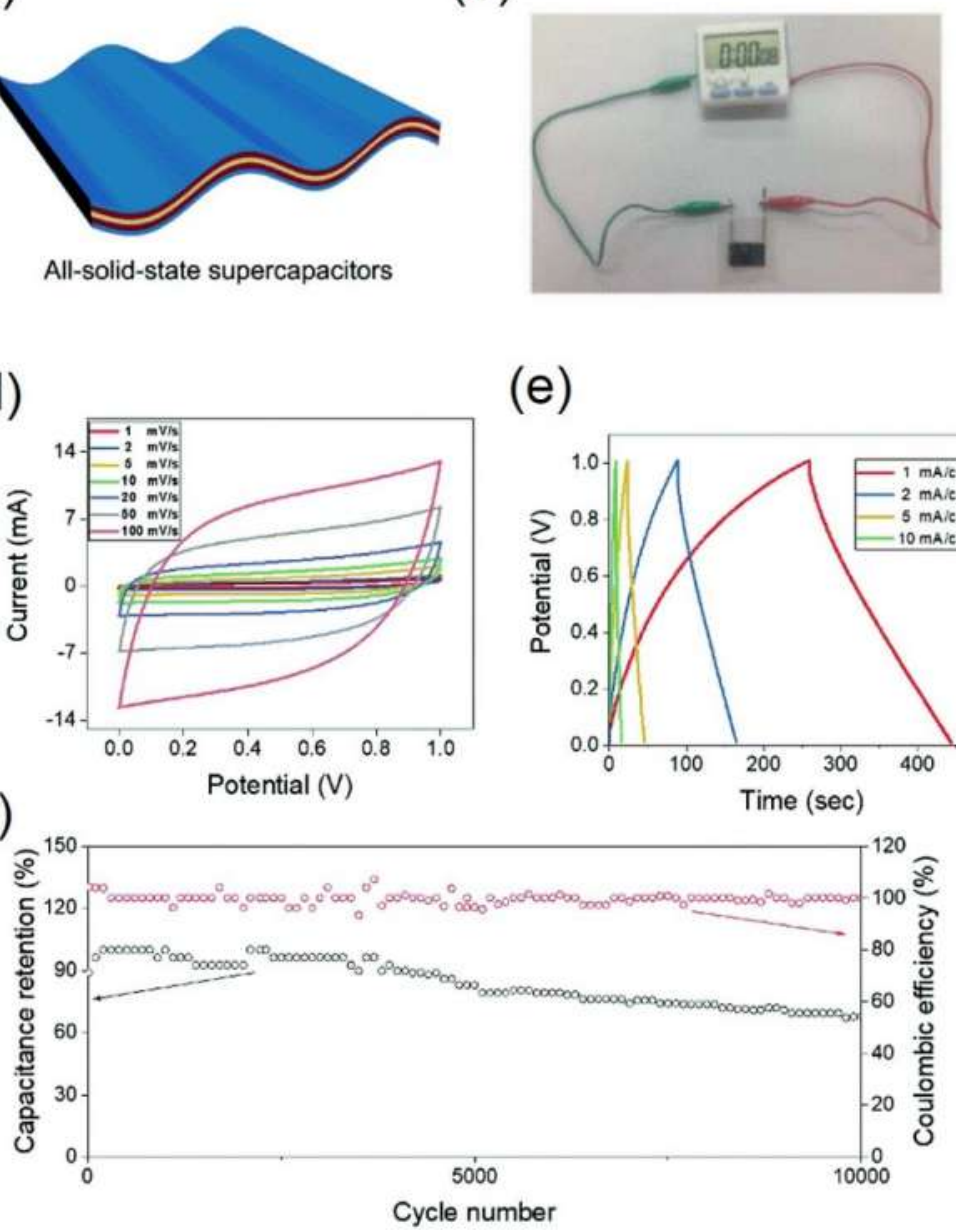

(e) (c)

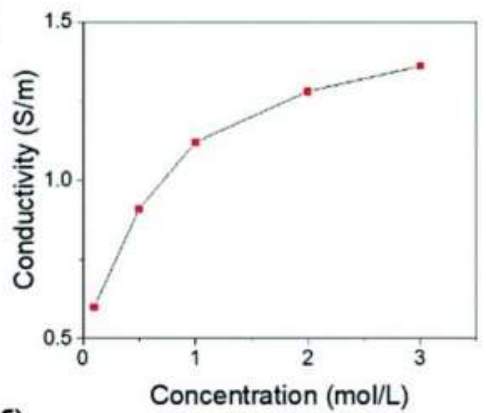

(f)

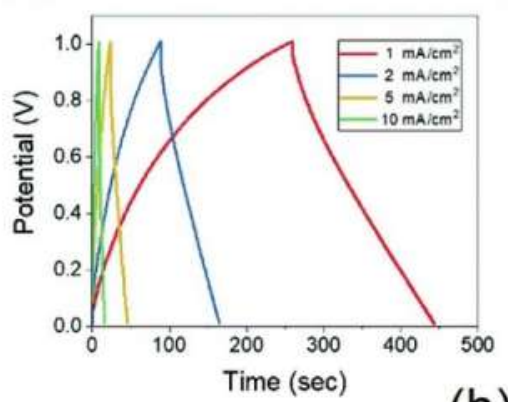

(h)
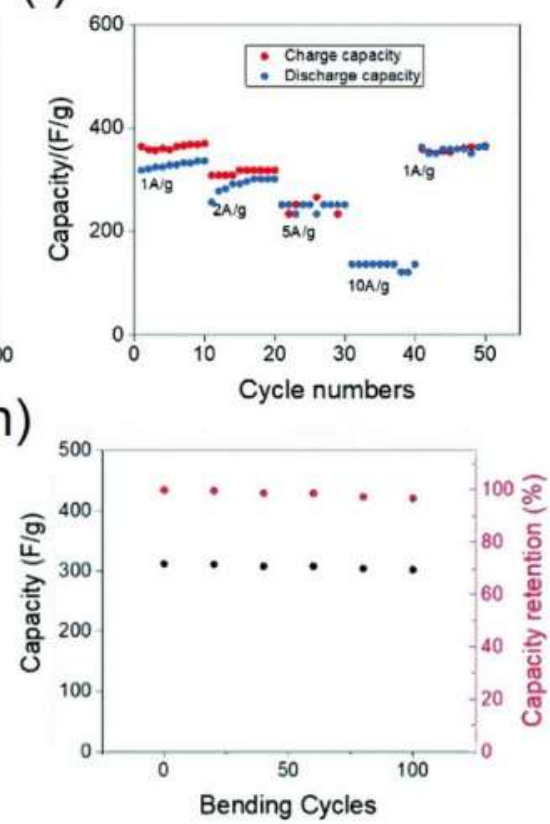

Figure 7. (a) Schematic of the all-solid-state supercapacitor. (b) Photograph of the supercapacitor powering an electric time meter. (c) Ionic conductivity of the xanthan- $\mathrm{Na}_{2} \mathrm{SO}_{4}$ electrolyte at different concentrations. (d) CV curves at different scan rates $\left(1-100 \mathrm{mV} \mathrm{s}{ }^{-1}\right.$ ). (e) GCD curves at different current densities $\left(1-10 \mathrm{~mA} \mathrm{~cm}^{-2}\right)$. (f) Rate performance at different current densities $\left(1-10 \mathrm{~A} \mathrm{~g}^{-1}\right)$. (g) Cycle performance. (h) Specific capacitance and capacity retention after many bending cycles. Reproduced with permission from ref 99 . Copyright 2019 Published by The Royal Society of Chemistry.

devices owing to their high-power density $\left(>10 \mathrm{~kW} \mathrm{~kg}^{-1}\right)$, fast charge/discharge capacity, long life cycle, and flexibility. ${ }^{140-142}$ The performance of supercapacitors is mainly determined by the physical characteristics of the electrode and electrolyte materials. In electrochemical double-layer capacitors (EDLCs), the energy storage occurs through the adsorption of ions at the interface between the electrodes and electrolyte, which suggests a non-faradic process (entirely electrostatic). ${ }^{143}$

Numerous studies assembled EDLCs based on bacterial polymer electrolytes (Table 2). Most of the studies reported specific capacitances relatively low compared to the capacitances of synthetic-based supercapacitors recently developed. For example, Kotatha et al. developed EDLCs based on BC gel coated with CTS and ALG electrolytes and activated carbon electrodes, both immersed in $\mathrm{EMImBF}_{4}{ }^{82}$ The discharge capacitance varied greatly at a current density from 2.5 to 100 $\mathrm{mA} \mathrm{cm}{ }^{-2}$. At the lowest current density, the EDLCs reached almost $120 \mathrm{~F} \mathrm{~g}^{-1}$, higher than the liquid-phase $\mathrm{EMImBF}_{4}$. However, BC electrolytes without CTS and ALG coating exhibited the lowest discharge capacitance at most current densities. Yu et al. assembled a supercapacitor based on nitrogen-doped porous carbon and aqueous $\mathrm{KOH}$ electrolyte that exhibited $341 \mathrm{~F} \mathrm{~g}^{-1}$ of specific capacitance at $1 \mathrm{~A} \mathrm{~g}^{-1}$ of current density. ${ }^{144}$ In contrast, the specific capacitances of capacitors based on DEX doped with $\mathrm{NH}_{4} \mathrm{Br}$, DEX-PVA blend doped with $\mathrm{NH}_{4} \mathrm{I}$, and CST-DEX blend doped with $\mathrm{LiClO}_{4}$ are limited to $1.61,4.20$, and $8.70 \mathrm{~F} \mathrm{~g}$, respectively. ${ }^{44,105,110}$ The specific capacitances of various synthetic supercapacitors are above $>250 \mathrm{~F} \mathrm{~g}^{-1}$. 145,146

However, two studies reported high-performance bacterialpolymer-based supercapacitors that can compete with the conventional ones. $\mathrm{Yu}$ et al. developed a supercapacitor based on $\mathrm{MnO}_{2}$-carbon nanotube (CNT) film electrodes and xanthan- $\mathrm{Na}_{2} \mathrm{SO}_{4}$ electrolyte (Figure 7a,b). ${ }^{99}$ The electrolyte alone exhibited outstanding ionic conductivity, reaching up to $1.12 \times 10^{-2} \mathrm{~S} \mathrm{~cm}^{-1}$ (Figure $7 \mathrm{c}$ ). The quasi-rectangular shape in the $\mathrm{CV}$ curves, even at $100 \mathrm{mV} \mathrm{s}^{-1}$, indicates good high-rate performance (Figure $7 \mathrm{~d}$ ), and the near triangular galvanostatic charge-discharge (GCD) curves suggest a fast chargedischarge cycle (Figure 7e). The supercapacitor exhibited a high specific capacitance $\left(347 \mathrm{~F} \mathrm{~g}^{-1}\right)$ at a current density of 1 $\mathrm{A} \mathrm{g}^{-1}$ and $128.8 \mathrm{~F} \mathrm{~g}^{-1}$ at $10 \mathrm{~A} \mathrm{~g}^{-1}$ (Figure 7f). The Coulombic efficiency maintained around $100 \%$ even after 10,000 charge/ discharge cycles. The specific capacitance dropped to $82 \%$ of the initial capacity after 5000 cycles and ended in $67.1 \%$ after 10,000 charge/discharge cycles (Figure $7 \mathrm{~g}$ ), which indicates 

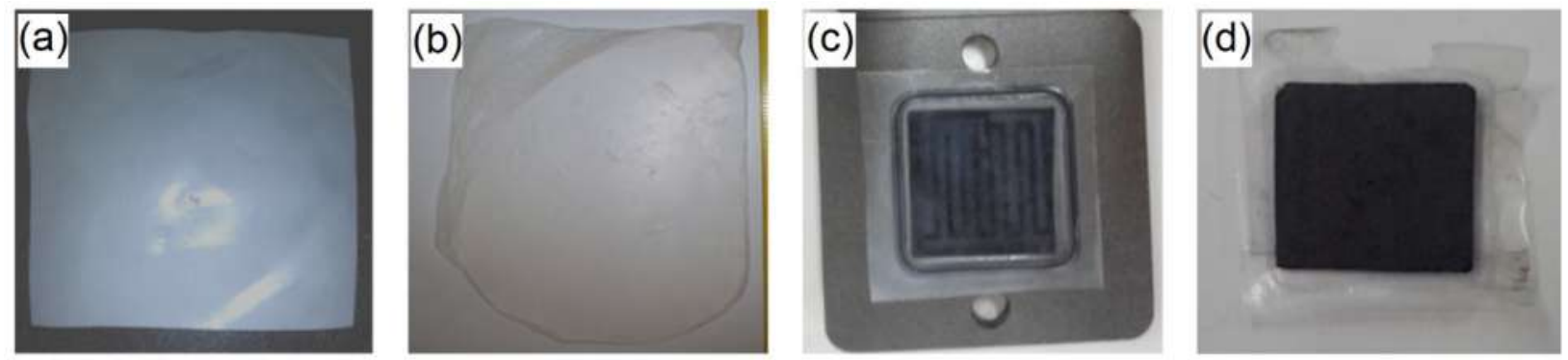

(e) 1
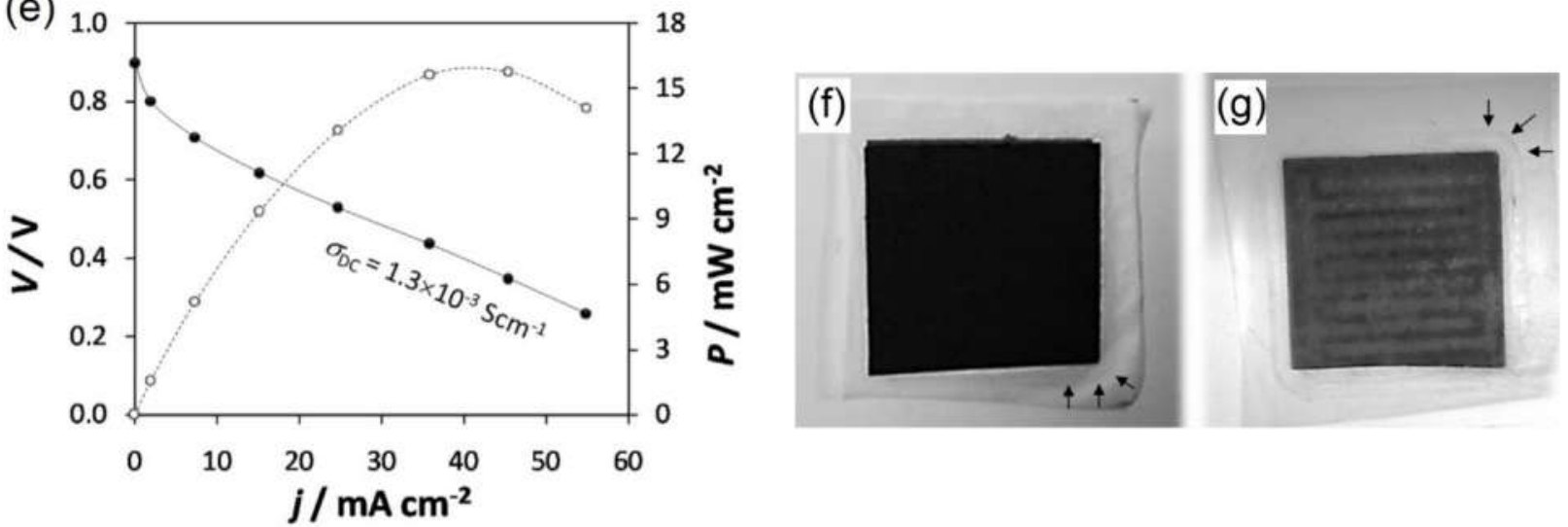

Figure 8. Photographs of (a) pure BC membrane, (b) Nafion-BC composite membrane, (c) Nafion-BC composite membrane MEA, and (d) Nafion-BC composite membrane MEA after fuel cell testing. (e) Power and polarization curves of the Nafion-BC composite membrane MEA. Reproduced with permission from ref 75. Copyright 2016 Published by Elsevier. Photographs of (f) pure BC and (g) BC-PSSA membrane after fuel cell testing. Reproduced with permission from ref 77. Copyright 2017 Published by Elsevier.

excellent reliability. Interestingly, the specific capacitance remained at $\sim 93 \%$ of its original value after 100 bending cycles (Figure $7 \mathrm{~h}$ ), proving to be a high-performance flexible supercapacitor. Wang et al. fabricated an all-BC supercapacitor based on $\mathrm{BC}$ immersed in $\mathrm{H}_{3} \mathrm{PO}_{4}$ as polymer electrolyte and activated pyrolyzed $\mathrm{BC}$ as the electrode material. ${ }^{147}$ The specific capacitance reached $241.8 \mathrm{~F} \mathrm{~g}^{-1}$ at a current density of $0.1 \mathrm{~A} \mathrm{~g} \mathrm{~g}^{-1}$ with a $92.9 \%$ capacitance retention after 10,000 charge-discharge cycles.

Other than EDLCs, Wang et al. developed a yarn supercapacitor based on twisted CNT-BC membranes with electrochemically deposited polypyrrole. ${ }^{148}$ The proposed yarn supercapacitor showed a high electrical performance, reaching an areal capacitance of $458 \mathrm{mF} \mathrm{cm} \mathrm{cm}^{-2}$ at a current density of 0.8 $\mathrm{mA} \mathrm{cm}{ }^{-2}$. Also, no significant reduction in capacitance was observed after 2000 cycles, which indicates a high cycling stability. Previous works with BC-polypyrrole yarn supercapacitors reached a maximum of $76.6 \mathrm{mF} \mathrm{cm}^{-2}$ areal capacitance, ${ }^{149}$ thus proving a significant step forward in the development of sustainable yarn supercapacitors.

4.3. Fuel Cells. Fuel cells offer a sustainable alternative to traditional power generation methods. Like supercapacitors and batteries, fuel cells are a type of energy conversion and storage device. $^{21}$ Proton exchange membrane fuel cells (PEMFCs) are devices that convert chemical energy from a fuel and oxidant into electrical energy by electrochemical reactions. ${ }^{150}$ PEMFCs consist of a proton-conducting membrane (electrolyte) sandwiched between cathode and anode catalyst layers. ${ }^{151}$ Gadim et al. prepared a membrane electrode assembly (MEA) using a Nafion-BC electrolyte and conventional $\mathrm{Pt} / \mathrm{C}$ electrodes on the carbon gas diffusion layer (Figure $8 \mathrm{a}-\mathrm{d}$ ). ${ }^{77}$ The open-circuit voltage reached $0.9 \mathrm{~V}$ and the maximum power density $16 \mathrm{~mW} \mathrm{~cm}^{-2}$ at $40 \mathrm{~mA} \mathrm{~cm}^{-2}$ of current density (Figure 8e). Moreover, the membrane was found to be remarkably degraded after testing (Figure 8d), which poses a challenge to the lifetime and reliability of the asprepared Nafion-BC electrolyte. Gadim et al. also tested the efficiency of a BC-PSSA MEA, demonstrating a better performance than the previous Nafion-BC MEA. ${ }^{73,77}$ Overall, the open-circuit voltage was $\sim 1 \mathrm{~V}$, and the power density was $40 \mathrm{~mW} \mathrm{~cm}^{-2}$ at $125 \mathrm{~mA} \mathrm{~cm}{ }^{-2}$ of current density. Additionally, the membrane did not show significant degradation marks after testing (Figure 8g). Jiang et al. prepared MEAs with NafionBC blends that underwent an annealing process. ${ }^{152}$ The lowest methanol permeability was observed in the annealed $1: 1$ (BC:Nafion ration) blend electrolyte, reaching $7.21 \times 10^{-7}$ $\mathrm{cm}^{2} \mathrm{~s}^{-1}$. Moreover, the PEMFC showed a maximum power density of $106 \mathrm{~mW} \mathrm{~cm} \mathrm{~cm}^{-2}$ at $382.4 \mathrm{~mA} \mathrm{~cm}^{-2}$. Vilela et al. evaluated the electrochemical performance of PSS-BC membranes $\left(1.73 \times 10^{-2} \mathrm{~S} \mathrm{~cm}^{-1}\right.$ protonic conductivity $)$ in single-chamber microbial fuel cells (MFCs). ${ }^{153}$ The results indicated the MFC with a culture of Shewanella frigidimarina delivered a power density of $2.42 \mathrm{~mW} \mathrm{~m}^{-2}$ and open circuit voltage of $0.44 \mathrm{~V}$. Lastly, Annapurna et al. tested the performance of Rhizobium sp. EPS-SSA MEA. ${ }^{124}$ The performance was much higher than previous MEAs, with a peak power density of $400 \mathrm{~mW} \mathrm{~cm}^{-2}$ at $1250 \mathrm{~mA} \mathrm{~cm}{ }^{-2}$. This may be attributed to the great protonic conductivity of the EPS-SSA electrolyte $\left(0.3 \times 10^{-2} \mathrm{~S} \mathrm{~cm}^{-1}\right)$. These results are comparable to those previously reported in PSSA-PVA MEA $\left(210 \mathrm{~mW} \mathrm{~cm}^{-2}\right.$ at $\left.500 \mathrm{~mA} \mathrm{~cm} \mathrm{~cm}^{-2}\right)$. The development of PEMCFs based on bacterial polymers is still in development, and further research is required to achieve competitive peak performance.

4.4. Other Applications. Other less investigated applications, such as dye-sensitized solar cells (DSSCs) and 
(a)

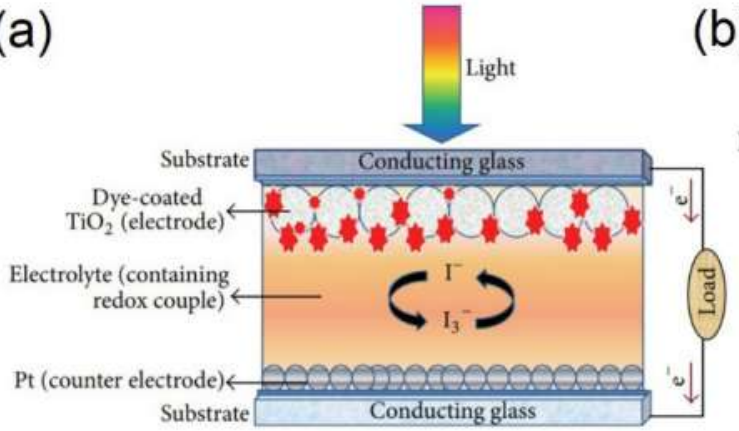

(c)

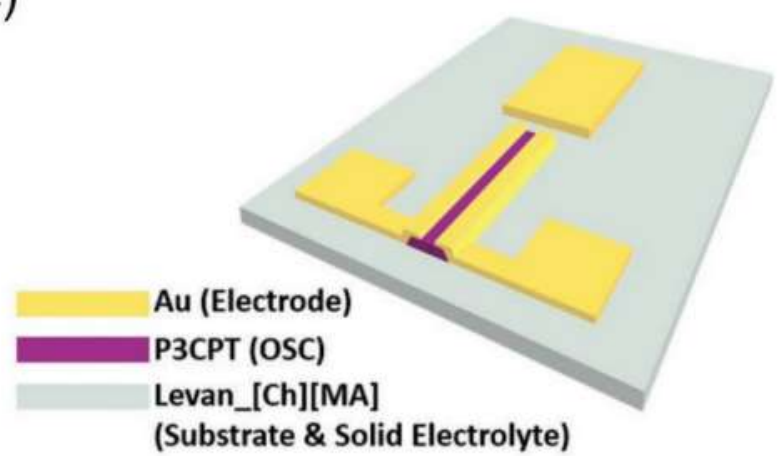

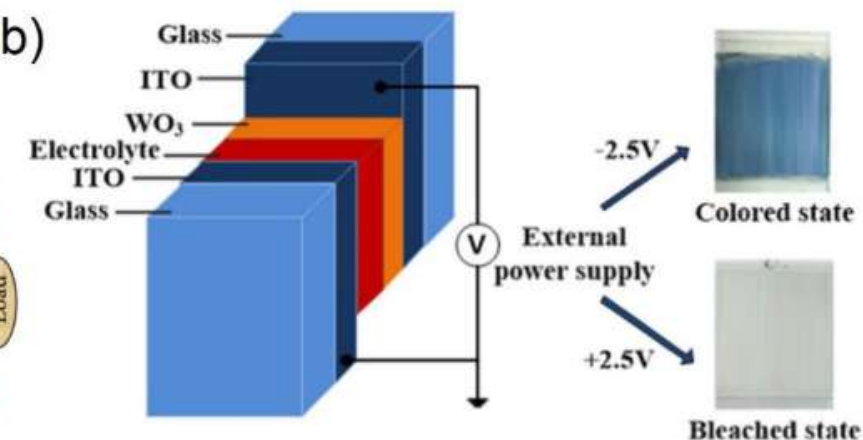

(d)

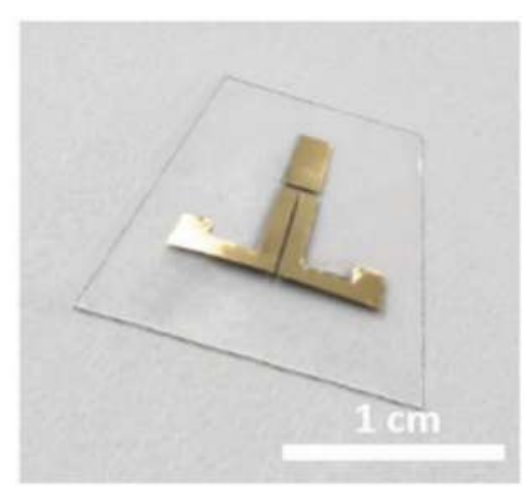

Figure 9. (a) Schematic of a typical DSSC. Reproduced with permission from ref 159. Copyright 2013 Published by Hindawi Publishing Corporation. (b) Schematic of a solid-state electrochromic device. Reproduced with permission from ref 160 . Copyright 2018 Published by Elsevier. (c) Schematic and (d) photograph of the organic transistor based on levan electrolyte. Reproduced with permission from ref 123. Copyright 2020 Published by Wiley-VCH.

electrochromic devices, have surged owing to the versatility and biocompatibility of bacterial polymers. DSSCs are sustainable energy devices that transform sunlight into electricity. DSSCs are a very attractive photovoltaic technology for being easy to manufacture, inexpensive, flexible, and versatile. ${ }^{154}$ In DSSCs, the electrolyte serves as a medium for the transfer charges by a redox couple (mostly $\mathrm{I}_{3}{ }^{-} / \mathrm{I}^{-}$) for dye regeneration (Figure 9a). ${ }^{155}$ Galliano et al. prepared a DSSC with a xanthan gum gel electrolyte that exhibited an opencircuit voltage of $0.62 \mathrm{~V}$ and short-circuit current density of $6.58 \mathrm{~mA} \mathrm{~cm}{ }^{-2}$. ${ }^{156}$ Singh et al. developed a DSSC based on gellan gum gel electrolyte doped with KI. The DSSC showed a short-circuit current density of $3.2 \times 10^{-3} \mathrm{~mA} \mathrm{~cm}^{-2}$, an opencircuit voltage of $0.57 \mathrm{~V}$, and a fill factor of $0.90 \%{ }^{119}$ These parameters remain very far from reaching the performance of conventional liquid electrolyte DSSCs.

Electrochromic devices reversibly change their optical state due to electrochemical reduction and oxidation reactions in response to an electric potential (Figure 9b). ${ }^{157}$ This technology is popular in autodimming mirrors, smart windows, and information displays. Neto et al. built an electrochromic device prototype based on gellan with $\left[\mathrm{N}_{1112(2(\mathrm{OH})}\right]\left[\mathrm{NTf}_{2}\right]$, glycerol, and $\mathrm{Er}\left(\mathrm{CF}_{3} \mathrm{SO}_{3}\right)_{3}$ and $\mathrm{WO}_{3} / \mathrm{CeO}_{2}-\mathrm{TiO}_{2}$ on ITO/ glass as the electrochromic material. ${ }^{55}$ The applied potential ranged from -3.0 to $2.8 \mathrm{~V}$ and exhibited an electrochromic contrast of $4.2 \%$ in the visible region. The efficiency at a wavelength of $555 \mathrm{~nm}$ was $3.5 \mathrm{~cm}^{-2} \mathrm{C}^{-1}$ in the colored state and $0.90 \mathrm{~cm}^{-2} \mathrm{C}^{-1}$ in the bleached state.

Organic transistors (OTs) are flexible and biocompatible components for biosensing, including recording biosignals. ${ }^{158}$ Jo et al. fabricated an organic transistor using levan as the substrate and solid electrolyte, poly[3-(5-carboxypentyl)thiophene-2,5-diyl] (P3CPT) as semiconductors, and gold electrodes (Figure 9c,d). ${ }^{123}$ The levan-based OT exhibited a high specific capacitance of $40 \mu \mathrm{F} \mathrm{cm} \mathrm{cm}^{-2}$ at $10 \mathrm{~Hz}$, mainly attributed to the addition of choline- and malate-based RTILs, and a reliability of $1.11 \%$ of effective bending strain and $5 \%$ of stretching. Electrocardiogram signals were successfully measured in human skin and heart of rat applying the levan-based OT. Levan-based OTs are presented as promising alternatives to conventional electrolyte components for biomedical applications.

\section{CONCLUSIONS}

Polymer electrolytes are key components for widely used electrochemical energy transformation and storage devices. Conventional polymer electrolytes require the use of toxic chemicals and non-biodegradable materials that compromise environmental and human health. Under this context, recent research focusing on bacterial polymer electrolytes display a promising alternative to conventional non-biodegradable components. In this review, we focused on the recent progress of bacterial-polymer-based electrolytes and their applications in electrochemical energy conversion and storage devices. Multiple studies reported high-performance bacterial polymer electrolytes in terms of thermal and mechanical properties and ionic conductivity. However, only a few studies achieved performances that are competitive with synthetic electrolytes. The desired properties of polymer electrolytes depend on the intended application. We describe the available approaches to tailor the physical and electrochemical properties of polymer electrolytes and those that were applied in bacterial-polymer- 
based electrolytes. Moreover, we summarized the development and performance of batteries, fuel cells, supercapacitors, and other electrochemical devices fabricated based on bacterial polymer electrolytes. Bacterial polymers are presented as a fruitful line of research in electrolyte materials for electrochemical applications due to their compatibility with multiple approaches, biodegradability, and high performance.

\section{ASSOCIATED CONTENT}

\section{(s) Supporting Information}

The Supporting Information is available free of charge at https://pubs.acs.org/doi/10.1021/acsaem.0c02195.

Full list of bacterial-polymer-based electrolytes and performance $(\mathrm{PDF})$

\section{AUTHOR INFORMATION}

\section{Corresponding Author}

Fernando G. Torres - Department of Mechanical

Engineering, Pontificia Universidad Católica del Perú, 150136 Lima, Peru; ㅇo이.org/0000-0002-3123-266X;

Email: fgtorres@pucp.pe

\section{Authors}

Gabriel E. De-la-Torre - Universidad San Ignacio de Loyola, Lima, Peru

Karen N. Gonzales - Department of Mechanical Engineering, Pontificia Universidad Católica del Perú, 150136 Lima, Peru

Omar P. Troncoso - Department of Mechanical Engineering, Pontificia Universidad Católica del Perú, 150136 Lima, Peru

Complete contact information is available at:

https://pubs.acs.org/10.1021/acsaem.0c02195

\section{Notes}

The authors declare no competing financial interest.

\section{ACKNOWLEDGMENTS}

This work was supported by the Vice-rectorate of Research of the Pontificia Universidad Catolica del Peru (VRI-PUCP).

\section{REFERENCES}

(1) Winter, M.; Brodd, R. J. What Are Batteries, Fuel Cells, and Supercapacitors? Chem. Rev. 2004, 104 (10), 4245-4269.

(2) Wang, Y.; Zhong, W. H. Development of Electrolytes towards Achieving Safe and High-Performance Energy-Storage Devices: A Review. ChemElectroChem 2015, 2 (1), 22-36.

(3) Yang, P.; Liu, L.; Li, L.; Hou, J.; Xu, Y.; Ren, X.; An, M.; Li, N. Gel Polymer Electrolyte Based on Polyvinylidenefluoride-CoHexafluoropropylene and Ionic Liquid for Lithium Ion Battery. Electrochim. Acta 2014, 115, 454-460.

(4) Yue, L.; Xie, Y.; Zheng, Y.; He, W.; Guo, S.; Sun, Y.; Zhang, T.; Liu, S. Sulfonated Bacterial Cellulose/Polyaniline Composite Membrane for Use as Gel Polymer Electrolyte. Compos. Sci. Technol. 2017, 145, 122-131.

(5) Stephan, A. M. Review on Gel Polymer Electrolytes for Lithium Batteries. Eur. Polym. J. 2006, 42 (1), 21-42.

(6) Snaith, H. J.; Schmidt-Mende, L. Advances in Liquid-Electrolyte and Solid-State Dye-Sensitized Solar Cells. Adv. Mater. 2007, 19 (20), 3187-3200.

(7) Marcinek, M.; Syzdek, J.; Marczewski, M.; Piszcz, M.; Niedzicki, L.; Kalita, M.; Plewa-Marczewska, A.; Bitner, A.; Wieczorek, P.; Trzeciak, T.; Kasprzyk, M.; Łęzak, P.; Zukowska, Z.; Zalewska, A.; Wieczorek, W. Electrolytes for Li-Ion Transport - Review. Solid State Ionics 2015, 276, 107-126.
(8) Cheng, X. B.; Zhang, R.; Zhao, C. Z.; Wei, F.; Zhang, J. G.; Zhang, Q. A Review of Solid Electrolyte Interphases on Lithium Metal Anode. Adv. Sci. 2016, 3 (3), 1500213.

(9) Fenton, D. E.; Parker, J. M.; Wright, P. V. Complexes of Alkali Metal Ions with Poly(Ethylene Oxide). Polymer 1973, 14 (11), 589.

(10) Su'ait, M. S.; Ahmad, A.; Hamzah, H.; Rahman, M. Y. A. Effect of Lithium Salt Concentrations on Blended 49\% Poly(Methyl Methacrylate) Grafted Natural Rubber and Poly(Methyl Methacrylate) Based Solid Polymer Electrolyte. Electrochim. Acta 2011, 57, 123-131.

(11) TianKhoon, L.; Ataollahi, N.; Hassan, N. H.; Ahmad, A. Studies of Porous Solid Polymeric Electrolytes Based on Poly (Vinylidene Fluoride) and Poly (Methyl Methacrylate) Grafted Natural Rubber for Applications in Electrochemical Devices. J. Solid State Electrochem. 2016, 20 (1), 203-213.

(12) Kang, S. E.; Lee, C. H. Perfluorinated Sulfonic Acid IonomerPTFE Pore-Filling Membranes for Polymer Electrolyte Membrane Fuel Cells. Membr. J. 2015, 25 (2), 171-179.

(13) Shi, Y.; Wu, C.; Li, L.; Yang, J. A Lithiated Perfluorinated Sulfonic Acid Polymer Electrolyte for Lithium-Oxygen Batteries. J. Electrochem. Soc. 2017, 164 (9), A2031-A2037.

(14) Elmér, A. M.; Jannasch, P. Solid Electrolyte Membranes from Semi-Interpenetrating Polymer Networks of PEG-Grafted Polymethacrylates and Poly(Methyl Methacrylate). Solid State Ionics 2006, 177 (5-6), 573-579.

(15) Vilela, C.; Silva, A. C. Q.; Domingues, E. M.; Gonçalves, G.; Martins, M. A.; Figueiredo, F. M. L.; Santos, S. A. O.; Freire, C. S. R. Conductive Polysaccharides-Based Proton-Exchange Membranes for Fuel Cell Applications: The Case of Bacterial Cellulose and Fucoidan. Carbohydr. Polym. 2020, 230, 115604.

(16) Alves, V. D.; Torres, C. A. V.; Freitas, F. Bacterial Polymers as Materials for the Development of Micro/Nanoparticles. Int. J. Polym. Mater. 2016, 65 (5), 211-224.

(17) More, T. T.; Yadav, J. S. S.; Yan, S.; Tyagi, R. D.; Surampalli, R. Y. Extracellular Polymeric Substances of Bacteria and Their Potential Environmental Applications. J. Environ. Manage. 2014, 144, 1-25.

(18) Moradali, M. F.; Rehm, B. H. A. Bacterial Biopolymers: From Pathogenesis to Advanced Materials. Nat. Rev. Microbiol. 2020, 18 (4), 195-210

(19) Rehm, B. H. A. Bacterial Polymers: Biosynthesis, Modifications and Applications. Nat. Rev. Microbiol. 2010, 8 (8), 578-592.

(20) Vandamme, E.; Bruggeman, G.; Debaets, S.; Vanhooren, P. Useful Polymers of Microbial Origin. Agro Food Ind. Hi-Tech 1996, 7 (5), $21-25$.

(21) Ngai, K. S.; Ramesh, S.; Ramesh, K.; Juan, J. C. A Review of Polymer Electrolytes: Fundamental, Approaches and Applications. Ionics 2016, 22 (8), 1259-1279.

(22) Long, L.; Wang, S.; Xiao, M.; Meng, Y. Polymer Electrolytes for Lithium Polymer Batteries. J. Mater. Chem. A 2016, 4 (26), 1003810039.

(23) Junoh, H.; Jaafar, J.; Nordin, N. A. H. M.; Ismail, A. F.; Othman, M. H. D.; Rahman, M. A.; Aziz, F.; Yusof, N. Performance of Polymer Electrolyte Membrane for Direct Methanol Fuel Cell Application: Perspective on Morphological Structure. Membranes (Basel, Switz.) 2020, 10 (3), 34.

(24) Yi, J.; Huo, Z.; Asiri, A. M.; Alamry, K. A.; Li, J. Development and Application of Electrolytes in Supercapacitors. Prog. Chem. 2018, 30 (11), 1624-1633.

(25) Jumaah, F. N.; Mobarak, N. N.; Ahmad, A.; Ghani, M. A.; Rahman, M. Y. A. Derivative of Iota-Carrageenan as Solid Polymer Electrolyte. Ionics 2015, 21 (5), 1311-1320.

(26) Torres, F. G.; Arroyo, J.; Alvarez, R.; Rodriguez, S.; Troncoso, O.; López, D. Carboxymethyl $\kappa / l$-Hybrid Carrageenan Doped with NH4I as a Template for Solid Bio-Electrolytes Development. Mater. Chem. Phys. 2019, 223, 659-665.

(27) Arockia Mary, I.; Selvanayagam, S.; Selvasekarapandian, S.; Srikumar, S. R.; Ponraj, T.; Moniha, V. Lithium Ion Conducting Membrane Based on K-Carrageenan Complexed with Lithium 
Bromide and Its Electrochemical Applications. Ionics 2019, 25 (12), $5839-5855$.

(28) Sangeetha, P.; Selvakumari, T. M.; Selvasekarapandian, S.; Srikumar, S. R.; Manjuladevi, R.; Mahalakshmi, M. Preparation and Characterization of Biopolymer K-Carrageenan with $\mathrm{MgCl} 2$ and Its Application to Electrochemical Devices. Ionics 2020, 26 (1), 233244.

(29) Osada, I.; De Vries, H.; Scrosati, B.; Passerini, S. Ionic-LiquidBased Polymer Electrolytes for Battery Applications. Angew. Chem., Int. Ed. 2016, 55 (2), 500-513.

(30) Ulaganathan, M.; Rajendran, S. Effect of Different Salts on PVAc/PVdF-Co-HFP Based Polymer Blend Electrolytes. J. Appl. Polym. Sci. 2010, 118 (2), 646-651.

(31) Iwaki, Y. O.; Escalona, M. H.; Briones, J. R.; Pawlicka, A. Sodium Alginate-Based Ionic Conducting Membranes. Mol. Cryst. Liq. Cryst. 2012, 554, 221-231.

(32) Bocharova, V.; Sokolov, A. P. Perspectives for Polymer Electrolytes: A View from Fundamentals of Ionic Conductivity. Macromolecules 2020, 53 (11), 4141-4157.

(33) Petrowsky, M.; Frech, R. Temperature Dependence of Ion Transport: The Compensated Arrhenius Equation. J. Phys. Chem. B 2009, 113 (17), 5996-6000.

(34) Nwanya, A. C.; Amaechi, C. I.; Udounwa, A. E.; Osuji, R. U.; Maaza, M.; Ezema, F. I. Complex Impedance and Conductivity of Agar-Based Ion-Conducting Polymer Electrolytes. Appl. Phys. A: Mater. Sci. Process. 2015, 119 (1), 387-396.

(35) Young, W. S.; Kuan, W. F.; Epps, T. H. Block Copolymer Electrolytes for Rechargeable Lithium Batteries. J. Polym. Sci., Part B: Polym. Phys. 2014, 52, 1-16.

(36) Hallinan, D. T.; Balsara, N. P. Polymer Electrolytes. Annu. Rev. Mater. Res. 2013, 43 (1), 503-525.

(37) Manthiram, A.; Yu, X.; Wang, S. Lithium Battery Chemistries Enabled by Solid-State Electrolytes. Nat. Rev. Mater. 2017, 2 (4), 116.

(38) Ramesh, N.; Duda, J. L. A Modified Free-Volume Model: Correlation of Ion-Conduction in Strongly Associating Polymeric Materials. J. Membr. Sci. 2001, 191 (1-2), 13-30.

(39) Moon, W. G.; Kim, G. P.; Lee, M.; Song, H. D.; Yi, J. A Biodegradable Gel Electrolyte for Use in High-Performance Flexible Supercapacitors. ACS Appl. Mater. Interfaces 2015, 7 (6), 3503-3511.

(40) Zeller, M.; Lorrmann, V.; Reichenauer, G.; Wiener, M.; Pflaum, J. Relationship Between Structural Properties and Electrochemical Characteristics of Monolithic Carbon Xerogel-Based Electrochemical Double-Layer Electrodes in Aqueous and Organic Electrolytes. Adv. Energy Mater. 2012, 2 (5), 598-605.

(41) Liu, X.; Wu, D.; Wang, H.; Wang, Q. Self-Recovering Tough Gel Electrolyte with Adjustable Supercapacitor Performance. Adv. Mater. 2014, 26 (25), 4370-4375.

(42) Runt, J.; Huang, J. Chapter 8 Polymer Blends and Copolymers. Handbook of Thermal Analysis and Calorimetry; Elsevier: 2002; Vol. 3, pp 273-294. DOI: 10.1016/S1573-4374(02)80011-5.

(43) Aziz, S. B.; Brza, M. A.; Mishra, K.; Hamsan, M. H.; Karim, W. O.; Abdullah, R. M.; Kadir, M. F. Z.; Abdulwahid, R. T. Fabrication of High Performance Energy Storage EDLC Device from Proton Conducting Methylcellulose: Dextran Polymer Blend Electrolytes. J. Mater. Res. Technol. 2020, 9 (2), 1137-1150.

(44) Aziz, S. B.; Hamsan, M. H.; Kadir, M. F. Z.; Karim, W. O.; Abdullah, R. M. Development of Polymer Blend Electrolyte Membranes Based on Chitosan: Dextran with High Ion Transport Properties for EDLC Application. Int. J. Mol. Sci. 2019, 20 (13), 3369.

(45) Kadir, M. F. Z.; Hamsan, M. H. Green Electrolytes Based on Dextran-Chitosan Blend and the Effect of NH4SCN as Proton Provider on the Electrical Response Studies. Ionics 2018, 24 (8), 2379-2398.

(46) Chapman, R. A. Chemical Bonding. In Handbook of Nonwovens; Elsevier Inc., 2006; pp 330-367. DOI: 10.1533/ 9781845691998.330.

(47) Nishimoto, A.; Agehara, K.; Furuya, N.; Watanabe, T.; Watanabe, M. High Ionic Conductivity of Polyether-Based Network
Polymer Electrolytes with Hyperbranched Side Chains. Macromolecules 1999, 32 (5), 1541-1548.

(48) Dave, P. N.; Gor, A. Natural Polysaccharide-Based Hydrogels and Nanomaterials: Recent Trends and Their Applications. Handbook of Nanomaterials for Industrial Applications; Elsevier: 2018; pp 36-66. DOI: 10.1016/B978-0-12-813351-4.00003-1.

(49) Fei, H.; Saha, N.; Oyunchimeg, Z.; Robert, M.; Kazantseva, N.; Wang, G.; Hua, B.; Petr, S. In Situ Preparation of Bacterial Cellulose Reinforced Hydrogel Electrolyte for Flexible Supercapacitors. 8th International Conference on Nanomaterials - Research \& Application 2016, 583-587.

(50) Caldeira, I.; Lüdtke, A.; Tavares, F.; Cholant, C.; Balboni, R.; Flores, W. H.; Galio, A.; Pawlicka, A.; Avellaneda, C. O. Ecologically Friendly Xanthan Gum-PVA Matrix for Solid Polymeric Electrolytes. Ionics 2018, 24 (2), 413-420.

(51) Tavares, F. C.; Dörr, D. S.; Pawlicka, A.; Oropesa Avellaneda, C. Microbial Origin Xanthan Gum-Based Solid Polymer Electrolytes. J. Appl. Polym. Sci. 2018, 135 (21), 46229.

(52) Xu, D.; Wang, B.; Wang, Q.; Gu, S.; Li, W.; Jin, J.; Chen, C.; Wen, Z. High-Strength Internal Cross-Linking Bacterial CelluloseNetwork-Based Gel Polymer Electrolyte for Dendrite-Suppressing and High-Rate Lithium Batteries. ACS Appl. Mater. Interfaces 2018, 10 (21), 17809-17819.

(53) Foroughi-Dahr, M.; Mostoufi, N.; Sotudeh-Gharebagh, R.; Chaouki, J. Particle Coating in Fluidized Beds. Reference Module in Chemistry, Molecular Sciences and Chemical Engineering; Elsevier: 2017. DOI: 10.1016/b978-0-12-409547-2.12206-1.

(54) Ramesh, S.; Bing, K. N. Conductivity, Mechanical and Thermal Studies on Poly(Methyl Methacrylate)-Based Polymer Electrolytes Complexed with Lithium Tetraborate and Propylene Carbonate. J. Mater. Eng. Perform. 2012, 21 (1), 89-94.

(55) Neto, M. J.; Sentanin, F.; Esperança, J. M. S. S.; Medeiros, M. J.; Pawlicka, A.; De Zea Bermudez, V.; Silva, M. M. Gellan Gum Ionic Liquid Membranes for Electrochromic Device Application. Solid State Ionics 2015, 274, 64-70.

(56) Wilkes, J. S. A Short History of Ionic Liquids - From Molten Salts to Neoteric Solvents. Green Chem. 2002, 4 (2), 73-80.

(57) Galiński, M.; Lewandowski, A.; Stepniak, I. Ionic Liquids as Electrolytes. Electrochim. Acta 2006, 51 (26), 5567-5580.

(58) Brazier, A.; Appetecchi, G. B.; Passerini, S.; Surca Vuk, A.; Orel, B.; Donsanti, F.; Decker, F. Ionic Liquids in Electrochromic Devices. Electrochim. Acta 2007, 52 (14), 4792-4797.

(59) Marcilla, R.; Alcaide, F.; Sardon, H.; Pomposo, J. A.; PozoGonzalo, C.; Mecerreyes, D. Tailor-Made Polymer Electrolytes Based upon Ionic Liquids and Their Application in All-Plastic Electrochromic Devices. Electrochem. Commun. 2006, 8 (3), 482-488.

(60) Sugumaran, T.; Silvaraj, D. S.; Saidi, N. M.; Farhana, N. K.; Ramesh, S.; Ramesh, K.; Ramesh, S. The Conductivity and Dielectric Studies of Polymer Electrolytes Based on Iota-Carrageenan with Sodium Iodide and 1-Butyl-3-Methylimidazolium Iodide for the DyeSensitized Solar Cells. Ionics 2019, 25 (2), 763-771.

(61) Yan, M.; Qu, W.; Su, Q.; Chen, S.; Xing, Y.; Huang, Y.; Chen, N.; Li, Y.; Li, L.; Wu, F.; Chen, R. Biodegradable Bacterial CelluloseSupported Quasi-Solid Electrolyte for Lithium Batteries. ACS Appl. Mater. Interfaces 2020, 12 (12), 13950-13958.

(62) Farhana, N. K.; Omar, F. S.; Shanti, R.; Mahipal, Y. K.; Ramesh, S.; Ramesh, K. Iota-Carrageenan-Based Polymer Electrolyte: Impact on Ionic Conductivity with Incorporation of AmNTFSI Ionic Liquid for Supercapacitor. Ionics 2019, 25 (7), 3321-3329.

(63) Nadia, S. R.; Khanmirzaei, M. H.; Ramesh, S.; Ramesh, K. Quasi-Solid-State Agar-Based Polymer Electrolytes for Dye-Sensitized Solar Cell Applications Using Imidazolium-Based Ionic Liquid. Ionics 2017, 23 (6), 1585-1590.

(64) Torres, F. G.; Arroyo, J. J.; Troncoso, O. P. Bacterial Cellulose Nanocomposites: An All-Nano Type of Material. Mater. Sci. Eng., C 2019, 98, 1277-1293.

(65) Nair, A. V.; Raman, M.; Doble, M. Polysaccharide-Based Hydrogels for Targeted Drug Delivery. Materials for Biomedical 
Engineering; Elsevier: 2019; pp 343-382. DOI: 10.1016/b978-0-12818435-6.00013-x.

(66) Xia, S.; Wu, X.; Zhang, Z.; Cui, Y.; Liu, W. Practical Challenges and Future Perspectives of All-Solid-State Lithium-Metal Batteries. Chem. 2019, 5 (4), 753-785.

(67) Simya, O. K.; Radhakrishnan, P.; Ashok, A.; Kavitha, K.; Althaf, R. Engineered Nanomaterials for Energy Applications. Handbook of Nanomaterials for Industrial Applications; Elsevier: 2018; pp 751-767. DOI: 10.1016/B978-0-12-813351-4.00043-2.

(68) Grande, C. J.; Torres, F. G.; Gomez, C. M.; Troncoso, O. P.; Canet-Ferrer, J.; Martinez-Pastor, J. Morphological Characterisation of Bacterial Cellulose-Starch Nanocomposites. Polym. Polym. Compos. 2008, 16 (3), 181.

(69) Czaja, W. K.; Young, D. J.; Kawecki, M.; Brown, R. M. The Future Prospects of Microbial Cellulose in Biomedical Applications. Biomacromolecules 2007, 8 (1), 1-12.

(70) Gea, S.; Torres, F. G.; Troncoso, O. P.; Reynolds, C. T.; Vilasecca, F.; Iguchi, M.; Peijs, T. Biocomposites Based on Bacterial Cellulose and Apple and Radish Pulp. Int. Polym. Process. 2007, 22 (5), 497-501.

(71) Abitbol, T.; Rivkin, A.; Cao, Y.; Nevo, Y.; Abraham, E.; BenShalom, T.; Lapidot, S.; Shoseyov, O. Nanocellulose, a Tiny Fiber with Huge Applications. Curr. Opin. Biotechnol. 2016, 39, 76-88.

(72) Yang, J.; Zhang, M.; Chen, Z.; Du, X.; Huang, S.; Tang, B.; Dong, T.; Wu, H.; Yu, Z.; Zhang, J.; Cui, G. Flame-Retardant QuasiSolid Polymer Electrolyte Enabling Sodium Metal Batteries with Highly Safe Characteristic and Superior Cycling Stability. Nano Res. 2019, 12 (9), 2230-2237.

(73) Torres, F. G.; Ccorahua, R.; Arroyo, J.; Troncoso, O. P. Enhanced Conductivity of Bacterial Cellulose Films Reinforced with NH4I-Doped Graphene Oxide. Polym. Technol. Mater. 2019, 58 (14), $1585-1595$.

(74) Ccorahua, R.; Troncoso, O. P.; Rodriguez, S.; Lopez, D.; Torres, F. G. Hydrazine Treatment Improves Conductivity of Bacterial Cellulose/Graphene Nanocomposites Obtained by a Novel Processing Method. Carbohydr. Polym. 2017, 171, 68.

(75) Gadim, T. D. O.; Vilela, C.; Loureiro, F. J. A.; Silvestre, A. J. D.; Freire, C. S. R.; Figueiredo, F. M. L. Nafion ${ }^{\circledR}$ and Nanocellulose: A Partnership for Greener Polymer Electrolyte Membranes. Ind. Crops Prod. 2016, 93, 212-218.

(76) Gadim, T. D. O.; Figueiredo, A. G. P. R.; Rosero-Navarro, N. C.; Vilela, C.; Gamelas, J. A. F.; Barros-Timmons, A.; Neto, C. P.; Silvestre, A. J. D.; Freire, C. S. R.; Figueiredo, F. M. L. Nanostructured Bacterial Cellulose-Poly(4-Styrene Sulfonic Acid) Composite Membranes with High Storage Modulus and Protonic Conductivity. ACS Appl. Mater. Interfaces 2014, 6 (10), 7864-7875.

(77) Gadim, T. D. O.; Loureiro, F. J. A.; Vilela, C.; Rosero-Navarro, N.; Silvestre, A. J. D.; Freire, C. S. R.; Figueiredo, F. M. L. Protonic Conductivity and Fuel Cell Tests of Nanocomposite Membranes Based on Bacterial Cellulose. Electrochim. Acta 2017, 233, 52-61.

(78) Vilela, C.; Silvestre, A. J. D.; Figueiredo, F. M. L.; Freire, C. S. R. Nanocellulose-Based Materials as Components of Polymer Electrolyte Fuel Cells. J. Mater. Chem. A 2019, 7 (35), 20045-20074.

(79) Choudhury, N. A.; Sampath, S.; Shukla, A. K. HydrogelPolymer Electrolytes for Electrochemical Capacitors: An Overview. Energy Environ. Sci. 2009, 2 (1), 55-67.

(80) Zhang, Y.; Chen, Y.; Li, X.; Alfred, M.; Li, D.; Huang, F.; Wei, Q. Bacterial Cellulose Hydrogel: A Promising Electrolyte for Flexible Zinc-Air Batteries. J. Power Sources 2021, 482, 228963.

(81) Fei, H.; Saha, N.; Kazantseva, N.; Wang, G.; Bao, H.; Saha, P. A Strong and Sticky Hydrogel Electrolyte for Flexible Supercapacitors. AIP Conf. Proc. 2015, 1779, 040012.

(82) Kotatha, D.; Morishima, K.; Uchida, S.; Ogino, M.; Ishikawa, M.; Furuike, T.; Tamura, H. Preparation and Characterization of Gel Electrolyte with Bacterial Cellulose Coated with Alternating Layers of Chitosan and Alginate for Electric Double-Layer Capacitors. Res. Chem. Intermed. 2018, 44 (8), 4971-4987.
(83) Yoshida, T.; Tokumasu, T. Molecular Dynamics Study of Proton Transfer Including Grotthus Mechanism in Polymer Electrolyte Membrane. ECS Trans. 2010, 33 (1), 1055-1065.

(84) Sun, H.; Sun, Z.; Wu, Y. Proton Transfer Mechanism in Perfluorinated Sulfonic Acid Polytetrafluoroethylene. Int. J. Hydrogen Energy 2012, 37 (17), 12821-12826.

(85) Zhao, N.; Wu, F.; Xing, Y.; Qu, W.; Chen, N.; Shang, Y.; Yan, M.; Li, Y.; Li, L.; Chen, R. Flexible Hydrogel Electrolyte with Superior Mechanical Properties Based on Poly(Vinyl Alcohol) and Bacterial Cellulose for the Solid-State Zinc-Air Batteries. ACS Appl. Mater. Interfaces 2019, 11 (17), 15537-15542.

(86) Ding, C.; Fu, X.; Li, H.; Yang, J.; Lan, J.; Yu, Y.; Zhong, W.; Yang, X. An Ultrarobust Composite Gel Electrolyte Stabilizing Ion Deposition for Long-Life Lithium Metal Batteries. Adv. Funct. Mater. 2019, 29 (43), 1904547.

(87) Becker, A.; Katzen, F.; Pühler, A.; Ielpi, L. Xanthan Gum Biosynthesis and Application: A Biochemical/Genetic Perspective. Appl. Microbiol. Biotechnol. 1998, 50 (2), 145-152.

(88) Coviello, T.; Matricardi, P.; Marianecci, C.; Alhaique, F. Polysaccharide Hydrogels for Modified Release Formulations. J. Controlled Release 2007, 119 (1), 5-24.

(89) Palaniraj, A.; Jayaraman, V. Production, Recovery and Applications of Xanthan Gum by Xanthomonas Campestris. J. Food Eng. 2011, 106 (1), 1-12.

(90) Kumar, A.; Rao, K. M.; Han, S. S. Application of Xanthan Gum as Polysaccharide in Tissue Engineering: A Review. Carbohydr. Polym. 2018, 180, 128-144.

(91) Habibi, H.; Khosravi-Darani, K. Effective Variables on Production and Structure of Xanthan Gum and Its Food Applications: A Review. Biocatal. Agric. Biotechnol. 2017, 10, 130-140.

(92) Di Palma, T. M.; Migliardini, F.; Gaele, M. F.; Corbo, P. Physically Cross-Linked Xanthan Hydrogels as Solid Electrolytes for Al/Air Batteries. Ionics 2019, 25 (9), 4209-4217.

(93) Di Palma, T. M.; Migliardini, F.; Gaele, M. F.; Corbo, P. Aluminum-Air Batteries with Solid Hydrogel Electrolytes: Effect of PH Upon Cell Performance. Anal. Lett. 2020,.

(94) Pawlicka, A.; Tavares, F. C.; Dörr, D. S.; Cholant, C. M.; Ely, F.; Santos, M. J. L.; Avellaneda, C. O. Dielectric Behavior and FTIR Studies of Xanthan Gum-Based Solid Polymer Electrolytes. Electrochim. Acta 2019, 305, 232-239.

(95) Di Palma, T. M.; Migliardini, F.; Caputo, D.; Corbo, P. Xanthan and $\kappa$-Carrageenan Based Alkaline Hydrogels as Electrolytes for Al/Air Batteries. Carbohydr. Polym. 2017, 157, 122-127.

(96) Migliardini, F.; Di Palma, T. M.; Gaele, M. F.; Corbo, P. Solid and Acid Electrolytes for Al-Air Batteries Based on Xanthan- $\mathrm{HCl}$ Hydrogels. J. Solid State Electrochem. 2018, 22 (9), 2901-2916.

(97) Sharma, V.; Kumar, R.; Arora, N.; Singh, S.; Sharma, N.; Anand, A.; Jain, S. K.; Sharma, S. Effect of Heat Treatment on Thermal and Mechanical Stability of $\mathrm{NaOH}$-Doped Xanthan GumBased Hydrogels. J. Solid State Electrochem. 2020, 24 (6), 1337-1347.

(98) Zhang, S.; Yu, N.; Zeng, S.; Zhou, S.; Chen, M.; Di, J.; Li, Q. An Adaptive and Stable Bio-Electrolyte for Rechargeable Zn-Ion Batteries. J. Mater. Chem. A 2018, 6 (26), 12237-12243.

(99) Yu, N.; Wang, X.; Zhang, S.; Zeng, S.; Zhang, Y.; Di, J.; Li, Q. All-Solid-State Supercapacitors Using a Highly-Conductive Neutral Gum Electrolyte. RSC Adv. 2019, 9 (15), 8169-8174.

(100) Soni, R.; Bhange, S. N.; Athira, E.; Chetry, R.; Kurungot, S. Synthesis of Ultrathin PEDOT on Carbon Nanotubes and Shear Thinning Xanthan Gum-H2 SO4Gel Electrolyte for Supercapacitors. ChemElectroChem 2019, 6 (6), 1861-1869.

(101) Huang, S.; Huang, G. The Dextrans as Vehicles for Gene and Drug Delivery. Future Med. Chem. 2019, 11 (13), 1659-1667.

(102) Chen, F.; Huang, G.; Huang, H. Preparation and Application of Dextran and Its Derivatives as Carriers. Int. J. Biol. Macromol. 2020, $145,827-834$.

(103) Huang, G.; Huang, H. Application of Dextran as Nanoscale Drug Carriers. Nanomedicine 2018, 13 (24), 3149-3158. 
(104) Angelin, J.; Kavitha, M. Exopolysaccharides from Probiotic Bacteria and Their Health Potential. Int. J. Biol. Macromol. 2020, 162, $853-865$.

(105) Hamsan, M. H.; Shukur, M. F.; Aziz, S. B.; Yusof, Y. M.; Kadir, M. F. Z. Influence of $\mathrm{NH} 4 \mathrm{Br}$ as an Ionic Source on the Structural/Electrical Properties of Dextran-Based Biopolymer Electrolytes and EDLC Application. Bull. Mater. Sci. 2020, 43 (1), 30.

(106) Hamsan, M. H.; Shukur, M. F.; Aziz, S. B.; Kadir, M. F. Z. Dextran from Leuconostoc Mesenteroides-Doped Ammonium SaltBased Green Polymer Electrolyte. Bull. Mater. Sci. 2019, 42 (2), 57.

(107) Hamsan, M. H.; Aziz, S. B.; Azha, M. A. S.; Azli, A. A.; Shukur, M. F.; Yusof, Y. M.; Muzakir, S. K.; Manan, N. S. A.; Kadir, M. F. Z. Solid-State Double Layer Capacitors and Protonic Cell Fabricated with Dextran from Leuconostoc Mesenteroides Based Green Polymer Electrolyte. Mater. Chem. Phys. 2020, 241, 122290.

(108) Aziz, S. B.; Hamsan, M. H.; Nofal, M. M.; Karim, W. O.; Brevik, I.; Brza, M. A.; Abdulwahid, R. T.; Al-Zangana, S.; Kadir, M. F. Z. Structural, Impedance and Electrochemical Characteristics of Electrical Double Layer Capacitor Devices Based on Chitosan: Dextran Biopolymer Blend Electrolytes. Polymers (Basel, Switz.) 2020, 12 (6), 1411.

(109) Aziz, S. B.; Hamsan, M. H.; Karim, W. O.; Kadir, M. F. Z.; Brza, M. A.; Abdullah, O. G. High Proton Conducting Polymer Blend Electrolytes Based on Chitosan:Dextran with Constant Specific Capacitance and Energy Density. Biomolecules 2019, 9 (7), 267.

(110) Aziz, S. B.; Brza, M. A.; Hamsan, M. H.; Kadir, M. F. Z.; Muzakir, S. K.; Abdulwahid, R. T. Effect of Ohmic-Drop on Electrochemical Performance of EDLC Fabricated from PVA: Dextran: NH4I Based Polymer Blend Electrolytes. J. Mater. Res. Technol. 2020, 9 (3), 3734-3745.

(111) Zia, K. M.; Tabasum, S.; Khan, M. F.; Akram, N.; Akhter, N.; Noreen, A.; Zuber, M. Recent Trends on Gellan Gum Blends with Natural and Synthetic Polymers: A Review. Int. J. Biol. Macromol. 2018, 109, 1068-1087.

(112) Kang, D.; Zhang, H.-B.; Nitta, Y.; Fang, Y.-P.; Nishinari, K. Polysaccharides: Bioactivity and Biotechnology; Springer International Publishing: 2015; pp 1627-1682. DOI: 10.1007/978-3-319-16298020.

(113) Das, M.; Giri, T. K. Hydrogels Based on Gellan Gum in Cell Delivery and Drug Delivery. J. Drug Delivery Sci. Technol. 2020, 56, 101586.

(114) Warren, H.; In Het Panhuis, M. Highly Conducting Composite Hydrogels from Gellan Gum, PEDOT:PSS and Carbon Nanofibres. Synth. Met. 2015, 206, 61-65.

(115) Palumbo, F. S.; Federico, S.; Pitarresi, G.; Fiorica, C.; Giammona, G. Gellan Gum-Based Delivery Systems of Therapeutic Agents and Cells. Carbohydr. Polym. 2020, 229, 115430.

(116) Noor, I. S. M.; Majid, S. R.; Arof, A. K.; Djurado, D.; Claro Neto, S.; Pawlicka, A. Characteristics of Gellan Gum-LiCF3SO3polymer Electrolytes. Solid State Ionics 2012, 225, 649-653.

(117) Noor, I. Determination of Charge Carrier Transport Properties of Gellan Gum-Lithium Triflate Solid Polymer Electrolyte from Vibrational Spectroscopy. High Perform. Polym. 2020, 32 (2), $168-174$.

(118) Halim, N. F. A.; Majid, S. R.; Arof, A. K.; Kajzar, F.; Pawlicka, A. Gellan Gum-LiI Gel Polymer Electrolytes. Mol. Cryst. Liq. Cryst. 2012, 554, 232-238.

(119) Singh, R.; Bhattacharya, B.; Rhee, H. W.; Singh, P. K. Solid Gellan Gum Polymer Electrolyte for Energy Application. Int. J. Hydrogen Energy 2015, 40 (30), 9365-9372.

(120) Sudhakar, Y N; Selvakumar, M; Krishna Bhat, D Effect of Acid Dopants in Biodegradable Gel Polymer Electrolyte and the Performance in an Electrochemical Double Layer Capacitor. Phys. Scr. 2015, 90 (9), 095702.

(121) de Siqueira, E. C.; Rebouças, J. de S.; Pinheiro, I. O.; Formiga, F. R. Levan-Based Nanostructured Systems: An Overview. Int. J. Pharm. 2020, 580, 119242.
(122) Combie, J.; Oner, E. T. From Healing Wounds to Resorbable Electronics, Levan Can Fill Bioadhesive Roles in Scores of Markets. Bioinspiration and Biomimetics 2019, 14 (1), 011001.

(123) Jo, Y. J.; Kim, H.; Ok, J.; Shin, Y.; Shin, J. H.; Kim, T. H.; Jung, Y.; Kim, T. Biocompatible and Biodegradable Organic Transistors Using a Solid-State Electrolyte Incorporated with Choline-Based Ionic Liquid and Polysaccharide. Adv. Funct. Mater. 2020, 30 (29), 1909707.

(124) Annapurna, B.; Meenakshi, S.; Bhat, S. D.; Seshadri, S. Microbial Extracellular Polysaccharide-Based Membrane in Polymer Electrolyte Fuel Cells. Chem. Eng. J. 2013, 231, 373-379.

(125) Gonzales, K. N.; Troncoso, O. P.; Torres, F. G.; López, D. Molecular $\alpha$-Relaxation Process of Exopolysaccharides Extracted from Nostoc Commune Cyanobacteria. Int. J. Biol. Macromol. 2020, 161, $1516-1525$

(126) Sanz-Luque, E.; Bhaya, D.; Grossman, A. R. Polyphosphate: A Multifunctional Metabolite in Cyanobacteria and Algae. Front. Plant Sci. 2020, 11, 938.

(127) Sun, C.; López, C. A.; Alonso, J. A. Elucidating the Diffusion Pathway of Protons in Ammonium Polyphosphate: A Potential Electrolyte for Intermediate Temperature Fuel Cells. J. Mater. Chem. A 2017, 5 (17), 7839-7844.

(128) Kluy, N.; Reeb, B. B. L.; Paschos, O.; Maglia, F.; Angioni, S.; Righetti, P. P.; Schneider, O.; Stimming, U. Ammonium Polyphosphate Composite Based Electrolytes for Intermediate Temperature Fuel Cells. ECS Trans. 2013, 50 (2), 1255-1261.

(129) Skovroinski, E.; de Oliveira, R. J.; Galembeck, A. Fast SelfHealing and Rebuildable Polyphosphate-Based Metallo-Gels with Mixed Ionic-Electronic Conductivity. J. Colloid Interface Sci. 2019, 533, 216-226.

(130) Bugnicourt, E.; Cinelli, P.; Lazzeri, A.; Alvarez, V. Polyhydroxyalkanoate (PHA): Review of Synthesis, Characteristics, Processing and Potential Applications in Packaging. eXPRESS Polym. Lett. 2014, 8 (11), 791-808.

(131) Philip, S.; Keshavarz, T.; Roy, I. Polyhydroxyalkanoates: Biodegradable Polymers with a Range of Applications. J. Chem. Technol. Biotechnol. 2007, 82 (3), 233-247.

(132) Chanprateep, S. Current Trends in Biodegradable Polyhydroxyalkanoates. J. Biosci. Bioeng. 2010, 110 (6), 621-632.

(133) Dall'Asta, V.; Berbenni, V.; Mustarelli, P.; Ravelli, D.; Samorì, C.; Quartarone, E. A Biomass-Derived Polyhydroxyalkanoate Biopolymer as Safe and Environmental-Friendly Skeleton in Highly Efficient Gel Electrolytes for Lithium Batteries. Electrochim. Acta 2017, 247, 63-70.

(134) Hazwan Hussin, M.; Tajudin, N. A.; Fatin, N.; Azani, S. M.; Paramasivam, M.; Mohamad Haafiz, M. K.; Kumar, S.; Yemloul, M. Physicochemical Studies of Kenaf Nanocrystaline Cellulose and Poly (3-Hydroxybutyrate-Co-3-Hydroxyhexanoate) as Filler for Lithium Perchlorate Based Polymer Electrolyte. Int. J. Electrochem. Sci. 2019, $14,1620-1633$

(135) Cho, J.; Jeong, S.; Kim, Y. Commercial and Research Battery Technologies for Electrical Energy Storage Applications. Prog. Energy Combust. Sci. 2015, 48, 84-101.

(136) Bruce, P. G.; Freunberger, S. A.; Hardwick, L. J.; Tarascon, J. M. LigO2 and LigS Batteries with High Energy Storage. Nat. Mater. 2012, 11 (1), 19-29.

(137) Li, W. Review-An Unpredictable Hazard in Lithium-Ion Batteries from Transition Metal Ions: Dissolution from Cathodes, Deposition on Anodes and Elimination Strategies. J. Electrochem. Soc. 2020, 167 (9), 090514.

(138) Higashi, S.; Lee, S. W.; Lee, J. S.; Takechi, K.; Cui, Y. Avoiding Short Circuits from Zinc Metal Dendrites in Anode by Backside-Plating Configuration. Nat. Commun. 2016, 7 (1), 1-6.

(139) Shin, D. W.; Guiver, M. D.; Lee, Y. M. Hydrocarbon-Based Polymer Electrolyte Membranes: Importance of Morphology on Ion Transport and Membrane Stability. Chem. Rev. 2017, 117 (6), 47594805. 
(140) Palchoudhury, S.; Ramasamy, K.; Gupta, R. K.; Gupta, A. Flexible Supercapacitors: A Materials Perspective. Front. Mater. 2019, 5,83 .

(141) Najib, S.; Erdem, E. Current Progress Achieved in Novel Materials for Supercapacitor Electrodes: Mini Review. Nanoscale Adv. 2019, 1 (8), 2817-2827.

(142) Wang, R.; Yao, M.; Niu, Z. Smart Supercapacitors from Materials to Devices. InfoMat 2020, 2 (1), 113-125.

(143) Chen, T.; Dai, L. Carbon Nanomaterials for High-Performance Supercapacitors. Mater. Today 2013, 16 (7-8), 272-280.

(144) Yu, J.; Fu, N.; Zhao, J.; Liu, R.; Li, F.; Du, Y.; Yang, Z. High Specific Capacitance Electrode Material for Supercapacitors Based on Resin-Derived Nitrogen-Doped Porous Carbons. ACS Omega 2019, 4 (14), 15904-15911.

(145) Li, Y.; Zheng, S.; Liu, X.; Li, P.; Sun, L.; Yang, R.; Wang, S.; Wu, Z.; Bao, X.; Deng, W. Conductive Microporous Covalent Triazine-Based Framework for High-Performance Electrochemical Capacitive Energy Storage. Angew. Chem., Int. Ed. 2018, 57 (27), 7992-7996.

(146) Wang, K.; Zhao, N.; Lei, S.; Yan, R.; Tian, X.; Wang, J.; Song, Y.; Xu, D.; Guo, Q.; Liu, L. Promising Biomass-Based Activated Carbons Derived from Willow Catkins for High Performance Supercapacitors. Electrochim. Acta 2015, 166, 1-11.

(147) Wang, X.; Kong, D.; Zhang, Y.; Wang, B.; Li, X.; Qiu, T.; Song, Q.; Ning, J.; Song, Y.; Zhi, L. All-Biomaterial Supercapacitor Derived from Bacterial Cellulose. Nanoscale 2016, 8 (17), 91469150.

(148) Wang, W.; Yang, Y.; Chen, Z.; Deng, Z.; Fan, L.; Guo, W.; Xu, J.; Meng, Z. High-Performance Yarn Supercapacitor Based on Directly Twisted Carbon Nanotube@bacterial Cellulose Membrane. Cellulose 2020, 27 (13), 7649-7661.

(149) Xu, Q.; Fan, L.; Yuan, Y.; Wei, C.; Bai, Z.; Xu, J. All-SolidState Yarn Supercapacitors Based on Hierarchically Structured Bacterial Cellulose Nanofiber-Coated Cotton Yarns. Cellulose 2016, 23 (6), 3987-3997.

(150) Xie, F.; Shao, Z.; Hou, M.; Yu, H.; Song, W.; Sun, S.; Zhou, L.; Yi, B. Recent Progresses in H2-PEMFC at DICP. J. Energy Chem. 2019, 36, 129-140.

(151) Breitwieser, M.; Klingele, M.; Vierrath, S.; Zengerle, R.; Thiele, S. Tailoring the Membrane-Electrode Interface in PEM Fuel Cells: A Review and Perspective on Novel Engineering Approaches. Adv. Energy Mater. 2018, 8 (4), 1701257.

(152) Jiang, G. P.; Zhang, J.; Qiao, J. L.; Jiang, Y. M.; Zarrin, H.; Chen, Z.; Hong, F. Bacterial Nanocellulose/Nafion Composite Membranes for Low Temperature Polymer Electrolyte Fuel Cells. J. Power Sources 2015, 273, 697-706.

(153) Vilela, C.; Cordeiro, D. M.; Boas, J. V.; Barbosa, P.; Nolasco, M.; Vaz, P. D.; Rudić, S.; Ribeiro-Claro, P.; Silvestre, A. J. D.; Oliveira, V. B.; Pinto, A. M. F. R.; Figueiredo, F. M. L.; Freire, C. S. R. Poly(4Styrene Sulfonic Acid)/Bacterial Cellulose Membranes: Electrochemical Performance in a Single-Chamber Microbial Fuel Cell. Bioresour. Technol. Rep. 2020, 9, 100376.

(154) Teo, L. P.; Buraidah, M. H.; Arof, A. K. PolyacrylonitrileBased Gel Polymer Electrolytes for Dye-Sensitized Solar Cells: A Review. Ionics 2020, 26 (9), 4215-4238.

(155) Tomar, N.; Agrawal, A.; Dhaka, V. S.; Surolia, P. K. Ruthenium Complexes Based Dye Sensitized Solar Cells: Fundamentals and Research Trends. Sol. Energy 2020, 207, 59-76.

(156) Galliano, S.; Bella, F.; Bonomo, M.; Viscardi, G.; Gerbaldi, C.; Boschloo, G.; Barolo, C. Hydrogel Electrolytes Based on Xanthan Gum: Green Route towards Stable Dye-Sensitized Solar Cells. Nanomaterials 2020, 10 (8), 1585.

(157) Rai, V.; Singh, R. S.; Blackwood, D. J.; Zhili, D. A Review on Recent Advances in Electrochromic Devices: A Material Approach. Adv. Eng. Mater. 2020, 22 (8), 2000082.

(158) Wang, J.; Ye, D.; Meng, Q.; Di, C.; Zhu, D. Advances in Organic Transistor-Based Biosensors. Adv. Mater. Technol. 2020, 5 (7), 2000218.
(159) Kushwaha, R.; Srivastava, P.; Bahadur, L. Natural Pigments from Plants Used as Sensitizers for TiO 2 Based Dye-Sensitized Solar Cells. J. Energy 2013, 2013, 654953.

(160) Ding, J.; Liu, Z.; Wei, A.; Chen, T. P.; Zhang, H. Study of Electrochromic Characteristics in the Near-Infrared Region of Electrochromic Devices Based on Solution-Processed Amorphous WO3 Films. Mater. Sci. Semicond. Process. 2018, 88, 73-78. 